\title{
Effect of Methyl Bromide Additions on the Flame Speed of Methane
}

\author{
Carl Halpern
}

(September 5, 1962)

\begin{abstract}
The effect of small quantities of methyl bromide, up to 0.5 percent by volume, on the flame speed of methane-air mixtures has been determined. Maximum flame speeds, at given experimental conditions, are reduced proportionately to the amount of methyl bromide added. Flame speeds of rich mixtures are reduced much more than are flame speeds of lean mixtures. Reaction zone thickness of methane-air flames is increased by the addition of methyl bromide and the thickness increases with the amount of methyl bromide.
\end{abstract}

\section{Introduction}

Halogenated hydrocarbons have long been used to extinguish fires, and the effect of these combustion inhibitors on various combustion parameters has been the subject of many investigations [1-10]. ${ }^{1}$ Limits of flammability, quenching distance, and laminar flame speed all have been found to be affected by these inhibitors. Effect of inhibitors on the limit of flammability has been the chief topic of these investigations. The effect on flame speed has been little studied and what work that has been published usually treats of the effects of several inhibitors on a given fuel; description of the effects of other experimental conditions are usually lacking $[1,2,9$, 10]. It was felt that a study of the effect of one inhibitor on flame speed under controlled experimental conditions would be of interest and of value. Methane was chosen as the fuel since we have had considerable experience in the determination of the flame speed of methane-air mixtures. Methyl bromide was chosen as the inhibitor.

\section{Apparatus and Procedure}

A description of the apparatus and method used to measure flame speeds has been presented earlier [14]. Briefly, the apparatus consists of drying and metering systems for air and fuel, and a nozzle, the exit of which is the burner port. Means are provided to control the temperature of the combustible mixture issuing from the nozzle. Flame speeds are determined by a total-area method, which is based on the measurement of the area of an enlarged photograph of the schlieren image of the flame.

It was decided to prepare mixtures of air and methyl bromide of the desired strength and to meter these mixtures, rather than to set up a third metering system for the small quantities of methyl bromide that would be required. Some error is introduced in the metering of these mixtures, since the sharp-

\footnotetext{
1 Figures in brackets indicate the literature references at the end of this paper.
}

edged orifice used was calibrated for air. However, since the maximum amount of methyl bromide added was only 0.5 percent by volume of the air, it was considered that the error would be tolerable.

The mixtures of methyl bromide and air were prepared in a 120 gallon $\left(16 \mathrm{ft}^{3}\right)$ steel tank. The tank was evacuated to a pressure of several microns and the methyl bromide admitted from its container. Rise in pressure was measured on a mercury manometer, read to 0.01 in. Air from a compressor was dried by passing first through a column of activated alumina and then through a cold trap immersed in a slush of dry ice in a mixture of equal parts by weight of chloroform and carbon tetrachloride. Water content of the air is thus kept at 0.03 percent by volume. The dried air was admitted slowly to the tank, and the final pressure, generally 130 psig, was read on a calibrated Bourdon gage to 0.1 psig.

The products of combustion, which contain hydrogen bromide and bromine, were drawn from the enclosure surrounding the burner by a large capacity vacuum pump. Air currents, set up by the pump, so disturbed the flames that the pump was shut off when photographs were taken.

Mixtures of $0.1,0.2,0.3,0.4$, and 0.5 percent by volume of methyl bromide in air were prepared. For each mixture, the variation of flame speed with mixture ratio, by weight, of methane to air plus methyl bromide was determined, gas velocity at the exit of the nozzle being constant. The ratio, by weight, of methane to air plus methyl bromide was varied from 0.054 to 0.072 , and the gas velocity at the port of the nozzle was varied from 3 to $6 \mathrm{fps}$. Control of the temperature of the combustible mixture was such that the maximum change in temperature during a single run of about $3 \mathrm{hr}$ duration was $3.7^{\circ} \mathrm{F}$. Actual gas temperatures ranged from about $90^{\circ} \mathrm{F}$ in the summer to about $75^{\circ} \mathrm{F}$ in the winter. The variation of flame speed with temperature was determined using a mixture ratio of methane to air of 0.060 (the air contained $0.2 \%$ methyl bromide), and a gas velocity of $4 \mathrm{fps}$; the temperature range in this determination was from 70 to $95^{\circ} \mathrm{F}$. Variation of flame speed with temperature was found to be 0.00328 fps per ${ }^{\circ} \mathrm{F}$, and this value was used to correct 
all flame speeds to a constant temperature of $75^{\circ} \mathrm{F}$. It is not expected that the rate of change of flame speed with temperature will differ appreciably with the relatively small amounts of methyl bromide added. Some previously unpublished data in our possession shows that the rate of change of flame speed with temperature is unaffected by changes in mixture ratio.

\section{Results}

Combustion of methane with air to which methyl bromide had been added proceeded smoothly. The outer mantle of the flames was colored brown by the formation of free bromine and the odor of bromine was noticeable. At lean conditions, the brown color began close to the base of the flame and extended to the tip. As flames became richer

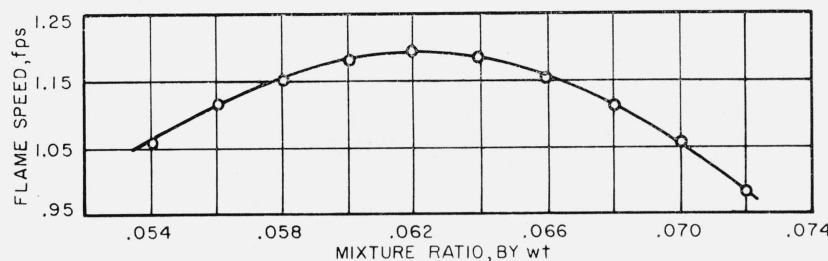

FIGURE 1. Variation of flame speed of methane with mixture ratio.

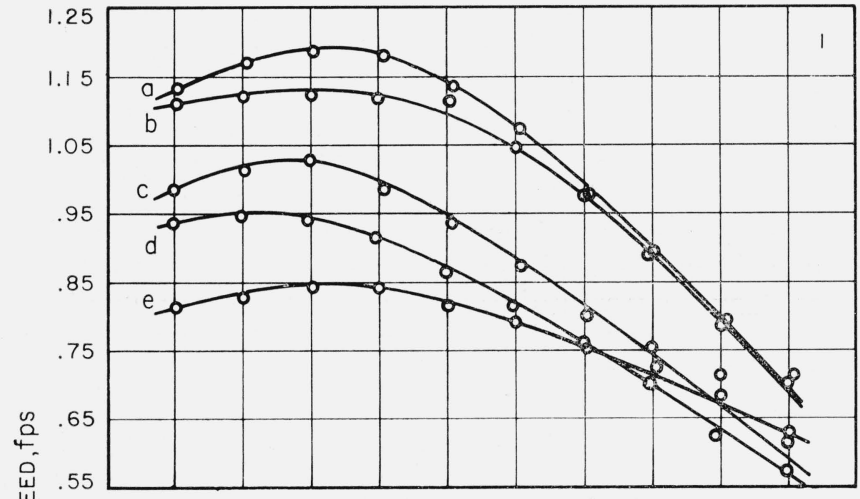

in

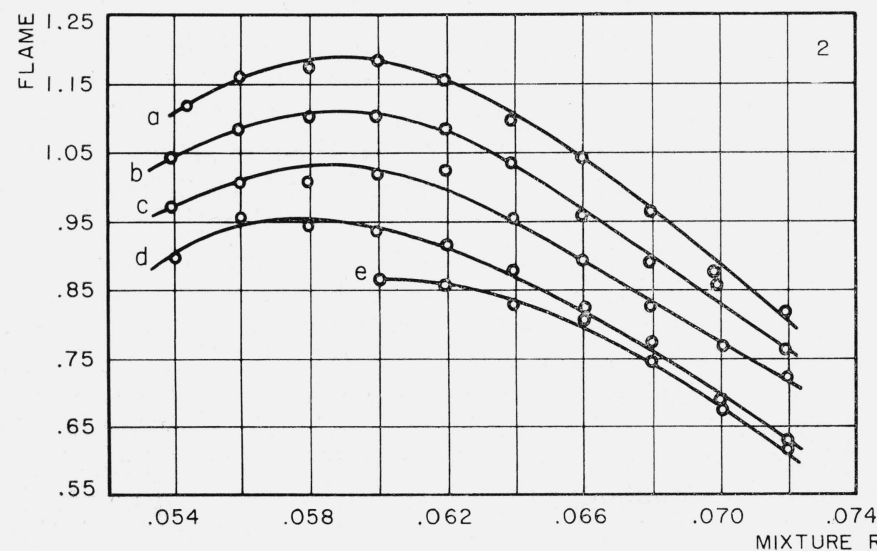

in fuel, the normal blue-green color of the inner cone appeared and the brown color was seen only near the tip of the outer mantle. As the concentration of methyl bromide was increased, the brown color became more intense, but in rich flames was visible only near the tip of the outer mantle. It is probable that hydrogen bromide is the original product and is converted to bromine by the overall reaction: $4 \mathrm{HBr}+\mathrm{O}_{2} \longrightarrow 2 \mathrm{Br}_{2}+2 \mathrm{H}_{2} \mathrm{O}$. Apparently there is insufficient oxygen in a rich flame for complete conversion of hydrogen bromide.

The variation of flame speed with mixture ratio for a methane-air flame is shown in figure 1 . This is taken from our previous work [14] with the values of flame speed corrected to $75^{\circ} \mathrm{F}$. The maximum flame speed is $1.196 \mathrm{frs}$, at a fuel-air ratio of 0.062 . At a fuel-air ratio of 0.054 , flame speed is $1.057 \mathrm{fps}$, and at a fuel-air ratio of 0.072 , flame speed is 0.980 fps.

Results of addition of methyl bromide are shown in figures 2 through 6 . It should be noticed that gas mixtures described as having the same mixture ratio but with different amounts of methyl bromide added do not have exactly the same ratio of fuel to air. As the amount of additive increases, the amount of air decreases, and the ratio between fuel and air increases; but this increase is only a matter of about a tenth of a percent. However, these facts should be remembered when comparing results. Figure 2
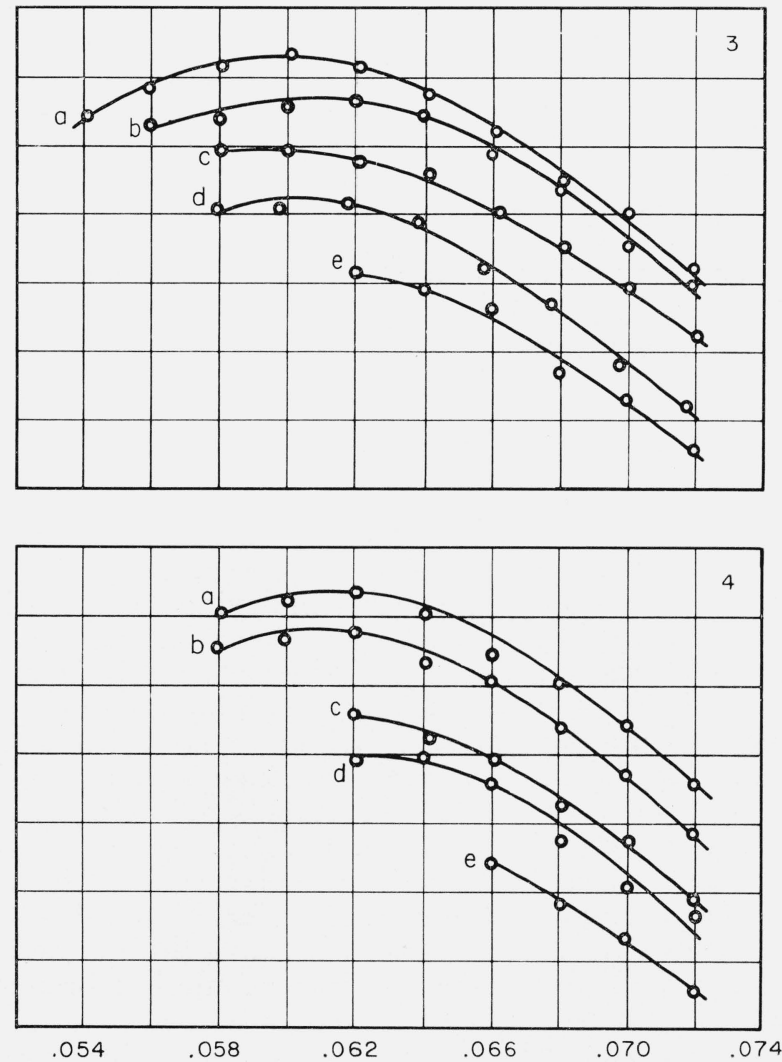

Figure 2. Effect of addition of methyl bromide on the flame speed of methane.

Percentage methyl bromide added: $a=0.1 ; b=0.2 ; c=0.3 ; d=0.4 ;$ and $e=0.5$. Gas velocity=1, $3 \mathrm{fps} ; 2,4 \mathrm{fps} ; 3,5 \mathrm{fps} ;$ and $4,6 \mathrm{fps}$. 
shows the variation of flame speed with mixture ratio, by weight, of methane to air plus methyl bromide, when $0.1,0.2,0.3,0.4$, and 0.5 percent by volume, respectively, of methyl bromide is added to air, and at gas velocities of $3,4,5$, and $6 \mathrm{fps}$.

For each addition of methyl bromide and at each gas velocity, there is found one value of mixture ratio at which flame speed is greatest. Maximum flame speed for a methane-air flame occurs at mixture racio 0.062 ; addition of methyl bromide causes maximum flame speed to shift to leaner conditions, especially at the lower gas velocities. (Stoichiometric for a methane-air flame is equivalent to a mixture ratio of 0.0583 .) Table 1 lists the maximum flame speeds and the experimental conditions at which they were observed.

TABLE 1. Maximum, flame speeds

\begin{tabular}{|c|c|c|c|c|}
\hline \multirow{2}{*}{$\begin{array}{l}\text { Flame } \\
\text { speed }\end{array}$} & $\mathrm{Wt} \mathrm{CH}_{4}$ & \multirow{2}{*}{$\begin{array}{c}\text { Percent } \mathrm{CH}_{3} \mathrm{Br} \\
\text { added to air }\end{array}$} & Flame speed & \multirow{2}{*}{$\begin{array}{c}\text { Gas } \\
\text { velocity }\end{array}$} \\
\hline & Wt air $+\mathrm{CH}_{3} \mathrm{Br}$ & & Flame speed $\mathrm{CH}_{4}$-air & \\
\hline $\begin{array}{c}f p s \\
1.196\end{array}$ & 0.062 & 0 &. & $\begin{array}{c}f p s \\
6\end{array}$ \\
\hline $\begin{array}{r}1.186 \\
1.125 \\
1.029 \\
0.945 \\
.843\end{array}$ & $\begin{array}{l}.058 \\
.058 \\
.058 \\
.056 \\
.060\end{array}$ & $\begin{array}{r}0.1 \\
.2 \\
.3 \\
.4 \\
.5\end{array}$ & $\begin{array}{r}0.992 \\
.941 \\
.860 \\
.790 \\
.704\end{array}$ & $\begin{array}{l}3 \\
3 \\
3 \\
3 \\
3\end{array}$ \\
\hline $\begin{array}{r}1.186 \\
1.103 \\
1.029 \\
0.958 \\
.864\end{array}$ & $\begin{array}{l}.060 \\
.060 \\
.062 \\
.056 \\
.060\end{array}$ & $\begin{array}{l}.1 \\
.2 \\
.3 \\
.4 \\
.5\end{array}$ & $\begin{array}{r}.992 \\
.922 \\
.860 \\
.801 \\
.722\end{array}$ & $\begin{array}{l}4 \\
4 \\
4 \\
4 \\
4\end{array}$ \\
\hline $\begin{array}{r}1.185 \\
1.117 \\
1.047 \\
0.967 \\
.867\end{array}$ & $\begin{array}{l}.060 \\
.062 \\
.058 \\
.062 \\
.062\end{array}$ & $\begin{array}{l}.1 \\
.2 \\
.3 \\
.4 \\
.5\end{array}$ & $\begin{array}{l}.991 \\
.934 \\
.875 \\
.806 \\
.724\end{array}$ & $\begin{array}{l}5 \\
5 \\
5 \\
5 \\
5\end{array}$ \\
\hline $\begin{array}{l}1.186 \\
1.127 \\
1.006 \\
0.945 \\
\text { จ. } 790\end{array}$ & $\begin{array}{l}.062 \\
.062 \\
.062 \\
.064 \\
.066\end{array}$ & $\begin{array}{l}.1 \\
.2 \\
.3 \\
.4 \\
.5\end{array}$ & $\begin{array}{l}.992 \\
.942 \\
.841 \\
.790 \\
.661\end{array}$ & $\begin{array}{l}6 \\
6 \\
6 \\
6 \\
6\end{array}$ \\
\hline
\end{tabular}

a Blow-off occurred at 0.064 .

Flash-back which represents the rich limit of operation of the burner was not encountered at any of the experimental conditions used. Blow-off which represents the lean limit of operation was rather frequent especially at gas velocities of 5 and $6 \mathrm{fps}$. No cases of blow-off were encountered at 3 fps and only one at $4 \mathrm{fps}$; this occurred at mixture ratio of 0.058 with 0.5 percent $\mathrm{CH}_{3} \mathrm{Br}$ added to the air. Table 2 lists the conditions at which the leanest flame could exist before blow-off occurred. It can be noted that as the amount of methyl bromide increases, the lean limit shifts toward fuel-rich conditions, while the flame speed becomes less. Rich flames are thus stabilized when methyl bromide is present.

Theoretically, the velocity with which combustible gas issues from a burner should have no effect on the flame speed. In practice, some variation of flame speed with gas velocity is noted [14]. In this present work, a small decrease of flame speed with increasing gas velocity, amounting to about 2 percent of the average value over the gas velocity range covered, was found at mixture ratios yielding maximum flame
TABLE 2. Lean limit of operation of burner

\begin{tabular}{|c|c|c|c|}
\hline $\begin{array}{l}\text { Percent } \mathrm{CH}_{3} \mathrm{Br} \\
\text { added to air }\end{array}$ & $\frac{\mathrm{Wt} \mathrm{CH}_{4}}{\mathrm{Wt} \mathrm{air}+\mathrm{CH}_{3} \mathrm{Br}}$ & $\begin{array}{c}\text { Gas } \\
\text { velocity }\end{array}$ & $\begin{array}{l}\text { Flame } \\
\text { speed }\end{array}$ \\
\hline $\begin{array}{l}0.1 \\
.2 \\
.2 \\
.3 \\
.3\end{array}$ & $\begin{array}{r}0.058 \\
.056 \\
.058 \\
.058 \\
.062\end{array}$ & $\begin{array}{r}f p s \\
6 \\
5 \\
6 \\
5 \\
6\end{array}$ & $\begin{array}{c}f p s \\
1.156 \\
1.084 \\
1.103 \\
1.047 \\
1.006\end{array}$ \\
\hline $\begin{array}{l}.4 \\
.4 \\
.5 \\
.5 \\
.5\end{array}$ & $\begin{array}{l}.058 \\
.062 \\
.060 \\
.062 \\
.066\end{array}$ & $\begin{array}{l}5 \\
6 \\
4 \\
5 \\
6\end{array}$ & $\begin{array}{l}.958 \\
.941 \\
.864 \\
.867 \\
.790\end{array}$ \\
\hline
\end{tabular}

speeds, and at leaner conditions. At rich conditions, flame speed increased with gas velocity, and the variation amounted to as much as 15 percent of the average value. Rich flames, however, are very tall as the flame speed is very low, and tall flames are very susceptible to disturbances. It is possible, therefore, that the increased variation of flame speed with gas velocity may be due to these disturbances.

The addition of methyl bromide to the combustion air reduces the maximum flame speed and the more methyl bromide added, the greater is the reduction in flame speed. Flames burning at mixture ratios greater than that at which maximum flame speed occurred are more affected by methyl bromide than are those burning at leaner conditions. At 0.1 percent methyl bromide addition, for example, and at a gas velocity of $3 \mathrm{fps}$, the maximum flame speed is $1.186 \mathrm{fps}$ at a mixture ratio of 0.058 . At a mixture ratio of 0.072 flame speed is $0.718 \mathrm{fps}$ which is 60.6 percent of the maximum, while at mixture ratio 0.054 , flame speed is $1.134 \mathrm{fps}$ which is 95.6 percent of the maximum. The corresponding percentages for the methane-air flame are 82.0 percent at mixture ratio 0.072 and 88.4 percent at mixture ratio 0.054 . The addition of 0.1 and 0.2 percent of methyl bromide even increases the flame speed at lean conditions. At a gas velocity of $3 \mathrm{fps}$, the flame speed at mixture ratio 0.054 is 1.134 fps for a 1 percent addition and 1.120 fps for 0.2 percent addition. For a methane-air flame, flame speed is $1.057 \mathrm{fps}$ at mixture ratio 0.054 and a gas velocity of $6 \mathrm{fps}$.

In figure 3 , flame speed is plotted against the percent of methyl bromide added to the combustion air. Mixture ratio is 0.062 and gas velocity is $5 \mathrm{fps}$. Flame speed decreases as the percentage of methyl bromide increases, and the data points fall along a straight line. For all experimental conditions of mixture ratio, gas velocity and methyl bromide addition, similar results were found. Hence, it may be deduced that the reduction in flame speed is directly proportional to the amount of methyl bromide, at least in the range of addition used in this work. In figure 4, the maximum flame speed at each addition of methyl bromide, at constant gas velocity, is plotted against the percentage of methyl bromide, and again the data points fall on a straight line, and the slopes of these lines are of similar magnitude. 
The reduction in maximum flame speed is directly proportional to the amount of methyl bromide added and amounts to $0.0828 \mathrm{fps}$ for each tenth percent of methyl bromide added.

In the method used for determining flame speeds, photographs of the schlieren and visible images of the flame are taken simultaneously on the same film. The schlieren image which depends on the change in density and thus on the change in temperature marks the position where chemical reactions begin in the flame [15]. The visible image indicates the region in the flame where reactions are completed [16] except for equilibrium changes. Hence, the separation between the schlieren and visible images is a measure of the thickness of the reaction zone. However, since both images in an enlarged photograph are rather diffuse, these measurements cannot be considered exact.

It is found that the thickness of the reaction zone varies with the flame speed; the greater the flame speed, the less is the thickness of the reaction zone. Figure 5 shows the variation of reaction zone thickness with mixture ratio at constant gas velocity; 0.2

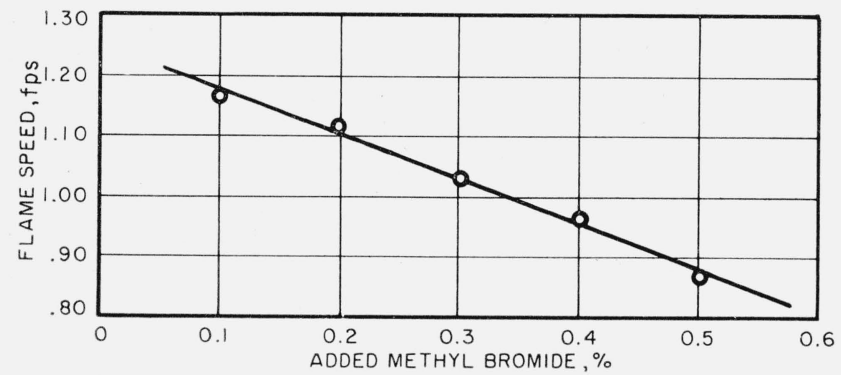

Figure 3. Variation of flame speed with added methy bromide.

Mixture ratio, by weight, $=0.062$. Gas velocity $=5 \mathrm{fps}$.

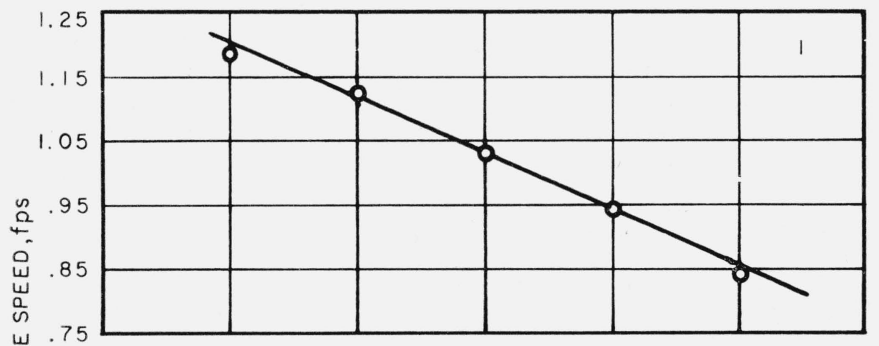

西

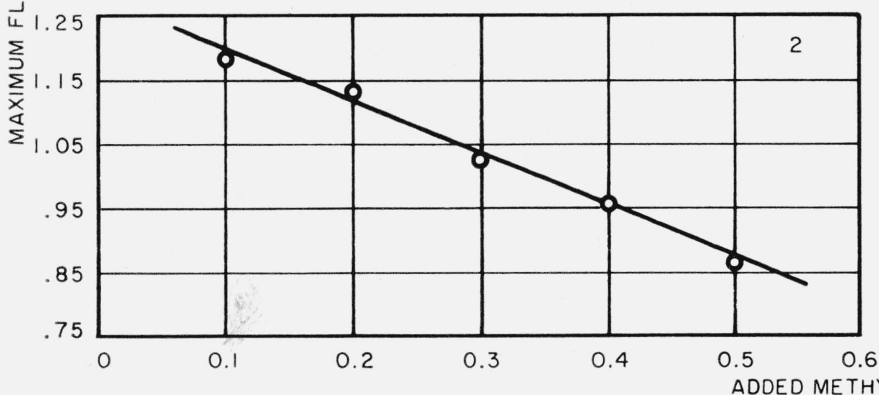

percent methyl bromide was added to the air and the gas velocity was $4 \mathrm{fps}$. Similar curves are obtained for all the other experimental conditions. Figure 6 shows the variation of reaction zone thickness with added methyl bromide at constant mixtureratio and at constant gas velocity. Mixture ratio was 0.070 and gas velocity was $6 \mathrm{fps}$. Zone thickness increases with the amount of methyl bromide added, and similar results were obtained at all other experimental conditions of mixture ratio and gas velocity. From some previously unreported experiments, it is found that the reaction zone thickness of a methane-air flame at fuel-air ratio of 0.070 and gas velocity of $6 \mathrm{fps}$ was $0.0180 \mathrm{in}$. Minimum thickness was 0.015 in. and occurred at mixture ratio 0.062 .

The mechanism of combustion inhibition by halogenated hydrocarbons is not fully understood $[5,9$, 11, 12]. Since the combustion of hydrocarbons in air involves the propagation of chain reactions by free radicals, it is plausible to assume that the presence of halogen results in the deactivation of one or more of the chain carrying radicals. Since deactivation would effectively decrease the rate of reaction, the general effect of chemical inhibitors in decreasing flame speeds would be explained. The increased reaction zone thickness which results on the addition of methyl bromide may also be explained by the effective decrease in reaction velocity.

The increase in flame speed noted at lean conditions at additions of 0.1 and 0.2 percent methyl bromide cannot be so explained. Since there is more oxygen in a lean flame, it may be that methyl bromide acts as a fuel rather than an inhibitor at this condition and the reaction mechanism is different. If methyl bromide acts as a fuel, then the mixture ratio should be expressed as $\frac{\text { wt methane }+ \text { wt methyl bromide }}{\text { wt air }}$, in which case the
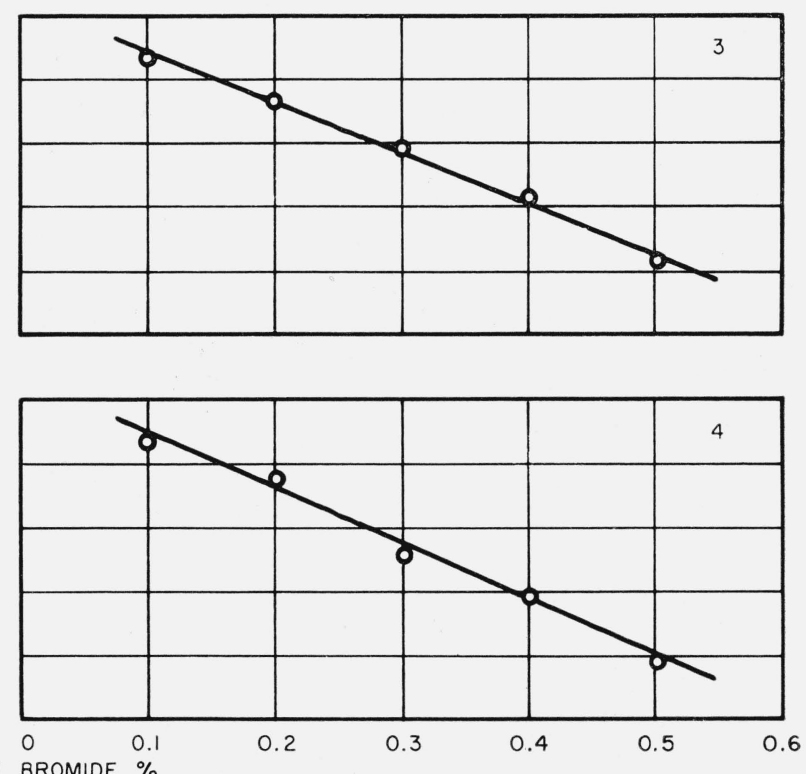

FIGURE 4. Variation of maximum flame speed with added methyl bromide. Gas velocity $-1,3$ fps; $2,4 \mathrm{fps} ; 3,5$ fps: and 4, 6 fps. 


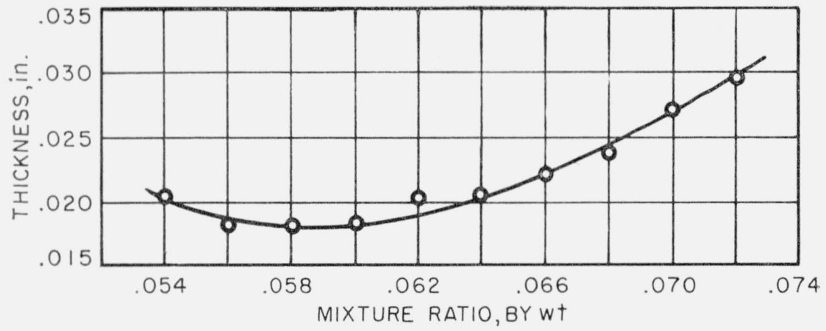

Figure 5. Variation of reaction zone thickness with mixture ratio.

0.2 percent methyl bromide added. Gas velocity $=4 \mathrm{fps}$.

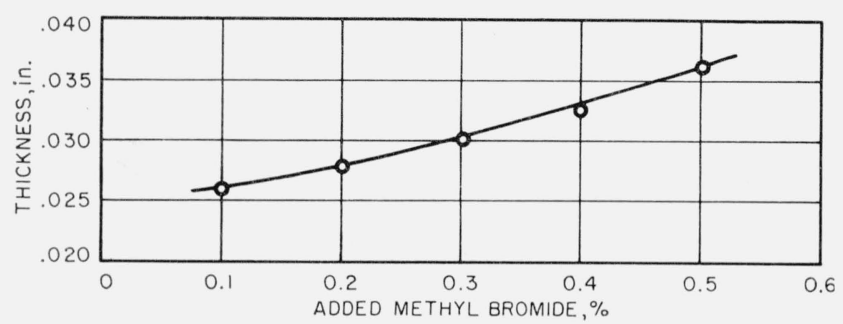

Figure 6. Variation of reaction zone thickness with added methyl bromide.

Mixture ratio 0.070 . Gas velocity $=6$ fps.

value is 0.057 instead of 0.054 , and 0.059 instead of 0.056 for the addition of 0.1 percent methyl bromide. Then if we superpose the curve for flame speed versus mixture ratio at 0.1 percent methyl bromide addition, using the new values of mixture ratio, on the curve for methane-air, the two curves agree for values of mixture ratio less than that at which maximum flame speed occurred.

\section{Experimental Observations}

Table 3 presents in detail observations on the effect of some variables on the flame speed and reaction zone thickness.

TABLE 3. Effect of some variables on flame speed

A. $0.1 \% \mathrm{CH}_{3} \mathrm{Br}$ added to air

\begin{tabular}{c|c|c|c|c}
\hline Wt $\mathrm{CH}_{4}$ & $\begin{array}{c}\text { Reaction zone } \\
\text { thickness }\end{array}$ & $\begin{array}{c}\text { Gas tempera- } \\
\text { ture }\end{array}$ & Flame speed & $\begin{array}{c}\text { Flame speed } \\
\text { corrected to } \\
75^{\circ} \mathrm{F}\end{array}$ \\
\hline Wt air $+\mathrm{CH}_{3} \mathrm{Br}$ &
\end{tabular}

1. Gas velocity $=3 \mathrm{fps}$

\begin{tabular}{l|r|r|r|r} 
& & & \\
0.05407 & in. & ${ }^{\circ} F$ & fps & \multicolumn{1}{c}{ fps } \\
.05608 & 0.0155 & 91.3 & 1.187 & 1.134 \\
.05807 & .0146 & 91.4 & 1.224 & 1.170 \\
.06013 & .0168 & 90.0 & 1.234 & 1.186 \\
.06216 & .0165 & 90.6 & 1.236 & 1.185 \\
.06410 & .0168 & 90.9 & 1.190 & 1.138 \\
.06610 & .0190 & 91.2 & 1.127 & 1.074 \\
.06800 & .0200 & 91.3 & 1.032 & .979 \\
.07013 & .0223 & 91.4 & .944 & .891 \\
.07214 & .0305 & 91.4 & .834 & .780 \\
& & 91.3 & .771 & .718 \\
\hline
\end{tabular}

TABLE 3. Effect of some variables on flame speed-Continued \begin{tabular}{c|c|c|c|c}
\hline Wt $\mathrm{CH}_{4}$ & $\begin{array}{c}\text { Reaction zone } \\
\text { thickness }\end{array}$ & $\begin{array}{c}\text { Gas tempera- } \\
\text { ture }\end{array}$ & Flame speed & $\begin{array}{c}\text { Flame speed } \\
\text { corrected to } \\
75^{\circ} \mathrm{F}\end{array}$ \\
\cline { 1 - 2 } Wir $+\mathrm{CH}_{3} \mathrm{Br}$ &
\end{tabular}

\begin{tabular}{|c|c|c|c|c|}
\hline \multicolumn{5}{|c|}{ 2. Gas velocity $=4 \mathrm{fps}$} \\
\hline $\begin{array}{r}0.05436 \\
.05592 \\
.05794 \\
.05992 \\
.06189 \\
.06387 \\
.06594 \\
.06794 \\
.06989 \\
.07196\end{array}$ & $\begin{array}{r}\text { in. } \\
0.0192 \\
.0172 \\
.0179 \\
.0202 \\
.0191 \\
.0195 \\
.0219 \\
.0235 \\
.0272 \\
.0295\end{array}$ & $\begin{array}{c}{ }^{\circ} F \\
\\
89.6 \\
87.8 \\
88.3 \\
88.9 \\
89.2 \\
89.6 \\
89.6 \\
89.3 \\
89.3 \\
89.3\end{array}$ & $\begin{array}{l}f p s \\
1.168 \\
1.203 \\
1.217 \\
1.232 \\
1.203 \\
1.143 \\
1.090 \\
1.014 \\
.923 \\
.866\end{array}$ & $\begin{array}{r}\text { fps } \\
1.120 \\
1.167 \\
1.174 \\
1.186 \\
1.156 \\
1.094 \\
1.042 \\
.967 \\
.876 \\
.818\end{array}$ \\
\hline \multicolumn{5}{|c|}{ 3. Gas velocity $=5 \mathrm{fps}$} \\
\hline $\begin{array}{r}0.05409 \\
.05593 \\
.05808 \\
.06010 \\
.06204 \\
.06406 \\
.06604 \\
.06809 \\
.07006 \\
.07204\end{array}$ & $\begin{array}{r}0.0198 \\
.0191 \\
.0203 \\
.0191 \\
.0224 \\
.0228 \\
.0218 \\
.0238 \\
.0267 \\
.0284\end{array}$ & $\begin{array}{l}86.6 \\
87.1 \\
87.0 \\
84.8 \\
85.8 \\
86.1 \\
86.6 \\
87.0 \\
86.9 \\
87.0\end{array}$ & $\begin{array}{r}1.133 \\
1.174 \\
1.207 \\
1.217 \\
1.201 \\
1.162 \\
1.108 \\
1.050 \\
.991 \\
.904\end{array}$ & $\begin{array}{r}1.094 \\
1.135 \\
1.168 \\
1.185 \\
1.167 \\
1.126 \\
1.070 \\
1.011 \\
.952 \\
.864\end{array}$ \\
\hline \multicolumn{5}{|c|}{ 4. Gas velocity $=6 \mathrm{fps}$} \\
\hline $\begin{array}{r}0.05807 \\
.06003 \\
.06200 \\
.06402 \\
.06601 \\
.06800 \\
.07003 \\
.07198\end{array}$ & $\begin{array}{r}0.0190 \\
.0203 \\
.0192 \\
.0212 \\
.0225 \\
.0238 \\
.0260 \\
.0287\end{array}$ & $\begin{array}{l}86.1 \\
86.2 \\
85.6 \\
84.9 \\
85.4 \\
86.0 \\
86.1 \\
86.3\end{array}$ & $\begin{array}{r}1.192 \\
1.208 \\
1.223 \\
1.186 \\
1.129 \\
1.092 \\
1.027 \\
.943\end{array}$ & $\begin{array}{r}1.156 \\
1.171 \\
1.186 \\
1.153 \\
1.095 \\
1.056 \\
.991 \\
.906\end{array}$ \\
\hline
\end{tabular}

B. $0.2 \% \mathrm{CH}_{3} \mathrm{Br}$ added to air

1. Gas velocity $=3 \mathrm{fps}$

\begin{tabular}{|c|c|c|c|c|}
\hline & in. & ${ }^{\circ} F$ & $f p s$ & fps \\
\hline 0.05406 & 0.0217 & 74.5 & 1.109 & 1. 110 \\
\hline .05601 & .0202 & 74.8 & 1. 121 & 1. 120 \\
\hline .05803 & .0201 & 75.2 & 1. 126 & 1. 125 \\
\hline 05998 & 0181 & 75.2 & 1. 120 & 1. 120 \\
\hline .06206 & .0207 & 75.5 & 1.115 & 1. 113 \\
\hline .06402 & .0221 & 75.3 & 1. 049 & 1. 048 \\
\hline .06599 & .0236 & 76.0 & .983 & .980 \\
\hline .06794 & .0251 & 75.6 & .890 & .889 \\
\hline .07000 & .0279 & 75.2 & .787 & .786 \\
\hline .07202 & .0328 & 75.1 & .706 & .706 \\
\hline
\end{tabular}

2. Gas velocity $=4 \mathrm{fps}$

\begin{tabular}{r|r|r|r|r}
\hline 0.05394 & 0.0203 & 77.7 & 1.053 & 1.044 \\
.05591 & .0182 & 75.8 & 1.088 & 1.085 \\
.05794 & .0182 & 75.8 & 1.105 & 1.103 \\
.05996 & .0183 & 75.9 & 1.106 & 1.103 \\
.06197 & .0203 & 76.1 & 1.092 & 1.088 \\
.06391 & .0205 & 76.4 & 1.038 & 1.033 \\
.06594 & .0220 & 76.9 & .966 & .960 \\
.06787 & .0237 & 77.2 & .899 & .892 \\
.06994 & .0272 & 77.4 & .859 & .851 \\
.07197 & .0295 & 79.5 & .778 & .764 \\
\hline
\end{tabular}

3. Gas velocity $=5 \mathrm{fps}$

\begin{tabular}{r|r|r|r|r}
\hline 0.05600 & 0.0190 & 77.2 & 1.091 & 1.084 \\
.05800 & .0178 & 77.5 & 1.098 & 1.090 \\
.05998 & .0198 & 76.7 & 1.115 & 1.110 \\
.06199 & .0200 & 76.6 & 1.122 & 1.117 \\
.06396 & .0207 & 76.6 & 1.102 & 1.097 \\
.06597 & .0218 & 76.8 & 1.043 & 1.037 \\
.06801 & .0230 & 76.9 & .995 & .989 \\
.06999 & .0258 & 77.1 & .912 & .906 \\
.07198 & .0278 & 77.2 & .882 & .874 \\
\hline
\end{tabular}


TABLE 3. Effect of some variables on flame speed-Continued

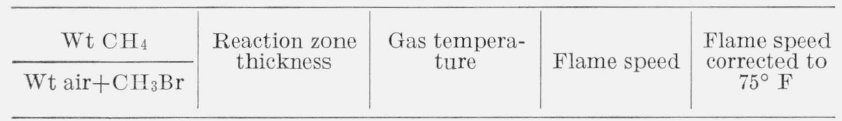

4. $\mathrm{G}$ as velocity $=6 \mathrm{fps}$

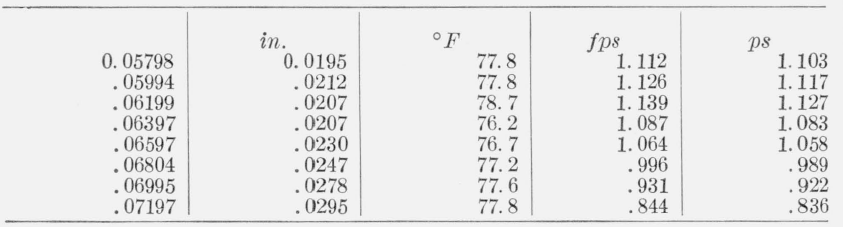

C. $0.3 \% \mathrm{CH}_{3} \mathrm{Br}$ added to air

1. Gas velocity $=3 \mathrm{fps}$

\begin{tabular}{|c|c|c|c|c|}
\hline $\begin{array}{l}0.05391 \\
.05602 \\
.05799 \\
.06019 \\
.06210 \\
.06414 \\
.06610 \\
.06810 \\
.06997 \\
.07196\end{array}$ & $\begin{array}{r}\text { in. } \\
0.0237 \\
.0253 \\
.0220 \\
.0234 \\
.0258 \\
.0237 \\
.0258 \\
.0295 \\
.0349 \\
.0395\end{array}$ & $\begin{array}{r}{ }^{\circ} F \quad \\
\quad 80.6 \\
80.0 \\
79.6 \\
79.8 \\
80.3 \\
80.4 \\
80.2 \\
80.6 \\
79.2 \\
79.3\end{array}$ & $\begin{array}{l}f p s \\
1.004 \\
1.029 \\
1.044 \\
1.001 \\
.956 \\
.892 \\
.817 \\
.747 \\
.701 \\
.631\end{array}$ & $\begin{array}{r}\text { fps } \\
0.985 \\
1.013 \\
1.029 \\
.985 \\
.939 \\
.874 \\
.800 \\
.729 \\
.687 \\
.617\end{array}$ \\
\hline
\end{tabular}

2. Gas velocity $=4 \mathrm{fps}$

\begin{tabular}{r|r|r|r|r}
\hline 0.05390 & 0.0203 & 78.3 & 0.984 & 0.973 \\
.05594 & .0200 & 77.3 & 1.016 & 1.008 \\
.05796 & .0190 & 76.5 & 1.013 & 1.008 \\
.05996 & .0228 & 76.7 & 1.024 & 1.019 \\
.06193 & .0217 & 77.1 & 1.036 & 1.029 \\
.06393 & .0252 & 78.3 & .965 & .954 \\
.06596 & .0240 & 79.1 & .909 & .896 \\
.06794 & .0260 & 78.9 & .839 & .827 \\
.07002 & .0299 & 77.9 & .778 & .769 \\
& .0297 & 77.2 & .729 & .722 \\
\hline
\end{tabular}

3. Gas velocity $=5 \mathrm{fps}$

\begin{tabular}{|c|c|c|c|c|}
\hline $\begin{array}{r}0.05804 \\
.06000 \\
.06211 \\
.06410 \\
.06613 \\
.06807 \\
.07006 \\
.07203\end{array}$ & $\begin{array}{r}0.0210 \\
.0222 \\
.0207 \\
.0215 \\
.0242 \\
.0270 \\
.0300 \\
.0350\end{array}$ & $\begin{array}{l}77.4 \\
76.6 \\
77.5 \\
76.2 \\
76.8 \\
77.2 \\
77.0 \\
76.5\end{array}$ & $\begin{array}{r}1.055 \\
1.045 \\
1.037 \\
1.013 \\
.959 \\
.913 \\
.847 \\
.757\end{array}$ & $\begin{array}{r}1.047 \\
1.040 \\
1.029 \\
1.009 \\
.953 \\
.906 \\
.840 \\
.752\end{array}$ \\
\hline \multicolumn{5}{|c|}{ 4. Gas velocity $=6 \mathrm{fps}$} \\
\hline $\begin{array}{r}0.06196 \\
.06418 \\
.06607 \\
.06804 \\
.07006 \\
.07198\end{array}$ & $\begin{array}{r}0.0232 \\
.0247 \\
.0272 \\
.0283 \\
.0300 \\
.0345\end{array}$ & $\begin{array}{l}77.8 \\
77.4 \\
78.9 \\
77.3 \\
77.4 \\
77.8\end{array}$ & $\begin{array}{r}1.015 \\
.981 \\
.955 \\
.884 \\
.833 \\
.749\end{array}$ & $\begin{array}{r}1.006 \\
.974 \\
.942 \\
.877 \\
.825 \\
.740\end{array}$ \\
\hline
\end{tabular}

D. $0.4 \% \mathrm{CH}_{3} \mathrm{Br}$ added to air

1. Gas velocity $=3 \mathrm{fps}$

\begin{tabular}{r|r|r|r|r}
\hline & in. & ${ }^{\circ} F$ & \multicolumn{1}{c}{ fps } & fps \\
0.05391 & 0.0203 & 72.5 & 0.930 & 0.938 \\
.05593 & .0207 & 73.9 & .941 & .945 \\
.05795 & .0209 & 75.0 & .942 & .942 \\
.05993 & .0218 & 75.4 & .918 & .917 \\
.06194 & .0225 & 75.8 & .872 & .869 \\
.06393 & .0248 & 74.6 & .811 & .812 \\
.06596 & .0270 & 72.7 & .745 & .752 \\
.06790 & .0315 & 72.9 & .708 & .701 \\
.06988 & .0372 & 74.6 & .628 & .623 \\
.07195 & .0408 & 75.3 & .576 & .575 \\
\hline
\end{tabular}

TABLE 3. Effect of some variables on flame speed-Continued

\begin{tabular}{|c|c|c|c|c|}
\hline $\mathrm{Wt} \mathrm{CH}_{4}$ & \multirow{2}{*}{$\begin{array}{l}\text { Reaction zone } \\
\text { thickness }\end{array}$} & \multirow{2}{*}{$\begin{array}{l}\text { Gas tempera- } \\
\text { ture }\end{array}$} & \multirow{2}{*}{ Flame speed } & \multirow{2}{*}{$\begin{array}{l}\text { Flame speed } \\
\text { corrected to } \\
75^{\circ} \mathrm{F}\end{array}$} \\
\hline $\mathrm{Wt}$ air $+\mathrm{CH}_{3} \mathrm{Br}$ & & & & \\
\hline \multicolumn{5}{|c|}{ 2. Gas velocity $=4 \mathrm{fps}$} \\
\hline $\begin{array}{l}0.05395 \\
.05591 \\
.05790 \\
.05995 \\
.06193 \\
.06395 \\
.06600 \\
.06798 \\
.07000 \\
.07196\end{array}$ & $\begin{array}{r}\text { in. } \\
0.0228 \\
.0227 \\
.0205 \\
.0217 \\
.0237 \\
.0248 \\
.0280 \\
.0303 \\
.0360 \\
.0397\end{array}$ & $\begin{array}{l}{ }^{\circ} F \quad \\
74.8 \\
75.1 \\
75.2 \\
74.8 \\
74.7 \\
74.7 \\
74.7 \\
74.8 \\
75.2 \\
75.4\end{array}$ & $\begin{array}{r}\text { fps } \\
0.895 \\
.958 \\
.945 \\
.935 \\
.916 \\
.877 \\
.804 \\
.770 \\
.677 \\
.628\end{array}$ & $\begin{array}{r}\text { fps } \\
0.896 \\
.958 \\
.944 \\
.936 \\
.917 \\
.878 \\
.805 \\
.771 \\
.676 \\
.627\end{array}$ \\
\hline \multicolumn{5}{|c|}{ 3. Gas velocit $y=5 \mathrm{fps}$} \\
\hline $\begin{array}{r}0.05795 \\
.05978 \\
.06177 \\
.06375 \\
.06578 \\
.06775 \\
.06978 \\
.07175\end{array}$ & $\begin{array}{r}0.0225 \\
.0227 \\
.0237 \\
.0258 \\
.0272 \\
.0300 \\
.0340 \\
.0393\end{array}$ & $\begin{array}{l}75.3 \\
75.3 \\
74.8 \\
73.2 \\
74.5 \\
75.2 \\
75.1 \\
74.2\end{array}$ & $\begin{array}{r}0.959 \\
.957 \\
.967 \\
.934 \\
.872 \\
.822 \\
.730 \\
.672\end{array}$ & $\begin{array}{r}0.958 \\
.957 \\
.967 \\
.940 \\
.873 \\
.821 \\
.730 \\
.674\end{array}$ \\
\hline \multicolumn{5}{|c|}{ 4. Gas velocity $=6 \mathrm{fps}$} \\
\hline $\begin{array}{r}0.06202 \\
.06399 \\
.06598 \\
.06801 \\
.07001 \\
.07204\end{array}$ & $\begin{array}{r}0.0233 \\
.0248 \\
.0260 \\
.0297 \\
.0325 \\
.0380\end{array}$ & $\begin{array}{l}84.6 \\
82.8 \\
83.0 \\
81.0 \\
81.6 \\
82.9\end{array}$ & $\begin{array}{r}0.972 \\
.971 \\
.934 \\
.843 \\
.778 \\
.741\end{array}$ & $\begin{array}{r}0.941 \\
.945 \\
.908 \\
.823 \\
.757 \\
.716\end{array}$ \\
\hline
\end{tabular}

E. $0.5 \% \mathrm{CH}_{3} \mathrm{Br}$ added to air

1. Gas velocity $=3 \mathrm{fps}$

\begin{tabular}{|c|c|c|c|c|}
\hline $\begin{array}{l}0.05399 \\
.05602 \\
.05802 \\
.06003 \\
.06200 \\
.06397 \\
.06596 \\
.06797 \\
.07001 \\
.07204\end{array}$ & $\begin{array}{r}\text { in. } \\
0.0248 \\
.0235 \\
.0233 \\
.0238 \\
.0240 \\
.0250 \\
.0265 \\
.0282 \\
.0328 \\
.0370\end{array}$ & $\begin{array}{l}{ }^{\circ} F \quad \\
\quad 80.1 \\
79.7 \\
79.9 \\
76.8 \\
77.6 \\
78.3 \\
78.6 \\
78.6 \\
80.0 \\
79.6\end{array}$ & $\begin{array}{l}\text { fps } \\
0.830 \\
.844 \\
.858 \\
.849 \\
.826 \\
.801 \\
.773 \\
.769 \\
.734 \\
.629\end{array}$ & $\begin{array}{r}\text { fps } \\
0.814 \\
.829 \\
.842 \\
.843 \\
.818 \\
.790 \\
.761 \\
.757 \\
.718 \\
.614\end{array}$ \\
\hline \multicolumn{5}{|c|}{ 2. Gas velocity $=4 \mathrm{fps}$} \\
\hline $\begin{array}{r}0.06000 \\
.06192 \\
.06396 \\
.06594 \\
.06793 \\
.07002 \\
.07194\end{array}$ & $\begin{array}{r}0.0230 \\
.0232 \\
.0252 \\
.0278 \\
.0307 \\
.0330 \\
.0387\end{array}$ & $\begin{array}{l}78.7 \\
79.3 \\
79.7 \\
80.0 \\
80.5 \\
80.7 \\
81.0\end{array}$ & $\begin{array}{r}0.876 \\
.871 \\
.844 \\
.811 \\
.761 \\
.706 \\
.633\end{array}$ & $\begin{array}{r}0.864 \\
.856 \\
.829 \\
.794 \\
.743 \\
.688 \\
.614\end{array}$ \\
\hline
\end{tabular}

3. Gas velocity $=5 \mathrm{fps}$

\begin{tabular}{|c|c|c|c|c|}
\hline $\begin{array}{r}0.06196 \\
.06398 \\
.06593 \\
.06793 \\
.06994 \\
.07199\end{array}$ & $\begin{array}{r}0.0275 \\
.0275 \\
.0311 \\
.0325 \\
.0377 \\
.0422\end{array}$ & $\begin{array}{l}75.0 \\
75.4 \\
74.6 \\
75.5 \\
75.6 \\
75.6\end{array}$ & $\begin{array}{r}0.867 \\
.841 \\
.813 \\
.719 \\
.682 \\
.604\end{array}$ & $\begin{array}{r}0.867 \\
.840 \\
.814 \\
.718 \\
.679 \\
.603\end{array}$ \\
\hline \multicolumn{5}{|c|}{ 4. Gas velocity $=6 \mathrm{fps}$} \\
\hline $\begin{array}{r}0.06599 \\
.06801 \\
.06999 \\
.07200\end{array}$ & $\begin{array}{r}0.0293 \\
.0323 \\
.0362 \\
.0415\end{array}$ & $\begin{array}{l}76.4 \\
75.5 \\
76.0 \\
75.8\end{array}$ & $\begin{array}{r}0.795 \\
.735 \\
.684 \\
.603\end{array}$ & $\begin{array}{r}0.790 \\
.733 \\
.681 \\
.601\end{array}$ \\
\hline
\end{tabular}




\section{Conclusions}

Small amounts of methyl bromide added to methane-air mixtures have a large effect on the flame speed. Maximum flame speed is reduced proportionately to the amount of methyl bromide added. Flame speed of rich mixtures is much more reduced than that of lean mixtures. Reaction zone thickness is increased by the presence of methyl bromide.

\section{References}

[1] R. F. Simmons and H. G. Wolfhard, Trans. Faraday Soc. 51, 1211 (1955).

[2] F. H. Garner, R. Long, A. J. Graham, and A. Badakhshan, Sixth Symposium (International) on Combustion, p. 802, Reinhold Pub. Corp., N.Y. (1957).

[3] M. C. Burdon, J. H. Burgoyne, and F. J. Weinburg, Fifth Symposium (International) on Combustion, p. 647, Reinhold Pub. Corp., N.Y. (1955)

[4] J. H. Burgoyne and G. Williams-Leir, Proc. Roy. Soc. A 193, 525 (1948).

[5] F. E. Belles and C. O'Neal, Jr., Sixth Symposium (International) on Combustion, p. 806, Reinhold Pub. Corp., N.Y. (1957).

[6] F. E. Belles, Nat. Advisory Comm. Aeronaut. Tech. Note 3565 (1955).
[7] J. E. Malcolm, Department of the Army, Engineering Research and Development Laboratories, Fort Belvoir, Va., Rept. 1177 (Aug. 18, 1950).

[8] E. C. Creitz, J. Research NBS 65A (Phys. and Chem.) No 4, 389 (1961).

[9] W. A. Rosser, H. Wise, and J. Meller, Seventh Symposium (International) on Combustion, p. 175, Butterworths Scientific Pub., London (1959).

[10] G. Lask and H. G. Wagner, Eighth Symposium (International) on Combustion, p. 432, Williams and Wilkins, Baltimore, Md. (1962).

[11] R. Friedman and J. B. Levy, Wright Air Development Center Tech. Rept. 56-568 (1957).

[12] R. Friedman, Fire Research Abstracts and Reviews 3, 128 (1961).

[13] A. Levy, J. W. Droege, J. Tighe, and J. F. Foster, Eighth Symposium (International) on Combustion, p. 524, Williams and Wilkins, Baltimore, Md. (1962).

[14] C. Halpern, J. Research NBS 60, 535 (1958) RP2867.

[15] J. J. Broeze, Third Symposium (International) on Combustion, p. 146, Williams and Wilkins, Baltimore, Md. (1949).

[16] A. G. Gaydon and H. G. Wolfhard, Flames, their structure, radiation, and temperature, p. 96, Chapman and Hall, Ltd., London (1960).

(Paper 67A1-196) 



\section{Publications of the National Bureau of Standards *}

\section{Selected Abstracts}

Reliability of a system in which spare parts deteriorate in storage, G. H. Weiss, J. Research NBS 66B (Math. and Math. Phys.) No. 4, 157 (Oct.-Dec. 1962). 75 cents.

The problem considered is that of determining the failure statisties for a system consisting of a single part and $n$ spares, in which it is assumed that that failure occurs at different rates in use and in storage. The resulting equations can be solved explicitly when both types of failures follow a Poisson law. Otherwise algorithms are given for the calculation of the failure probabilities.

Laguerre expansions for successive generations of a renewal process, G. H. Weiss, J. Research NBS 66B (Math. and Math. Phys.) No. 4, 165 (Oct.-Dec. 1962). 75 cents.

It is shown that the coefficients in the Laguerre expansions for successive generations in a renewal process are related by an algebraic convolution. Thus the calculations are easily mechanized for computation.

An application of information theory to the analysis of contingency tables, with a table of $2 n \ln n, n=1(1) 10,000$, S. Kullback, M. Kupperman, and H. H. Ku, J. Research NBS $66 \mathrm{~B}$ (Math. and Math. Phys.) No. 4, 217 (Oct.-Dec. 1962). 75 cents.

In this paper we present a number of useful tests for contingency tables in conjunction with a useful table to assist in the necessary computations. A consistent and simple approach based on the notions of information theory is used in developing the various test procedures and the results are analyzed in the form of analysis-of-information tables. Beginning with tests of hypotheses for a one-way table, tests of hypotheses of specified probabilities, independence, conditional independence, homogeneity of classifications, symmetry, and interaction are developed or indicated for contingency tables of two, three, four, and higher order classifications. Extension of these procedures to certain tests for Markov chains is indicated. Worked examples are given throughout the paper. A table of $2 n \ln n$ for $n=1(1) 10,000$ is appended for use in computation.

Use of surface refractivity in the empirical prediction of total atmospheric refraction, W. R. Iliff and J. M. Holt, J. Research NBS 6\%D (Radio Prop.) No. 131 (Jan,-Feb. 1963). 70 cents.

The use of a $1.9-\mathrm{cm}$ radio sextant capable of precise tracking of the sun has produced accurate measurements of total atmospheric microwave refraction. These data are used to verify the high correlation of such refraction with surface refractivity for low altitude angles. The values of the correlation coefficients obtained vary from 92.2 percent at 16 degrees to 98 percent at 2 degrees. An empirical predictor is developed, based on this correlation, which satisfactorily accounts for the observed refraction. The mathematical form of the predictor is given, and suggestions are made for its use.

Composition of reflection and transmission formulae $\mathrm{J}$. Heading, J. Research NBS 6\%D (Radio Prop.) No. 165 (Jan.-Feb. 1983). 70 cents.

An integral equation for the electric field in a continuously stratified ionized medium is derived; this is then manipulated to yield equations for the reflection and transmission coefficients, at the same time being susceptible to physical interpretation. The equations are solved by successive approximations, the first terms being a Fresnel-type coefficients. Various applications of the results are discussed.
Titheridge coefficients for the polynomial method of deducing electron density profiles from inograms A. R. Long and J. O. Thomas, J. Research NBS 6\%D (Radio Prop.) No. 179 (Jan.-Feb. 1963). 70 cents.

Sets of Titheridge polynomial coefficients suitable for the conversion into electron density profiles of smooth virtual height frequency curves, such as those observed regularly at night, are presented for a series of values of the magnetic dip angle and gyrofrequency. These magnetic conditions have been chosen so that the coefficients are suitable for the analysis, to a reasonable degree of accuracy, of ordinary and extraordinary ray records obtained anywhere in the world.

The coefficients may be used for the analysis of topsidesounder data to a first order of accuracy if the plasma frequency at the satellite is small.

Chemistry of cement. Proceedings of the Fourth International Symposium, Washington, 1960, NBS Mono. 43, Vol. I (Aug. 31, 1962), \$5.75; Vol. II (Sept. 27, 1962), \$5.50. The two volumes are available at $\$ 11.25$ a set.

This two-volume Monograph contains the complete texts of all papers given at the Fourth International Symposium on the Chemistry of Cement, held in Washington, D.C., October $2-7,1960$. The publication represents one of the most complete reference works available on the subject, and presents the latest information in most of the fields of cement chemistry research. Topics covered, divided according to session titles: Volume I, Chemistry of clinker, chemistry of hydration of cement compounds, and chemistry of hydration of portland cement; Volume II, Properties of cement paste and concrete destructive processes in concrete, chemical additions and admixtures, and special cements.

Tables of Eisenstein functions. Vibrational contributions to the thermodynamic functions, J. Hilsenrath and G. G. Ziegler, NBS Mono. 49 (July 12, 1952) \$2.75.

Tables are presented for the contribution of a harmonic oscillator to the free energy function, enthalpy function, entropy, and heat capacity of gases. Dimensionless values of the Planck-Einstein functions are given as a function of $x=H c / k T$ for $\quad x=0.0010(.0001) \quad 0.1500(.001) \quad 4.000(.01)$ $10.00(.2) 16.0$. A second table which gives the contributions in $\mathrm{cal} /$ mole ${ }^{\circ} \mathrm{K}$ directly as a function of frequency $\mu$, and temperature $T$, was computed using the values 1.43880 for the second radiation constant $h c / k$, and 1.98717 for the universal gas constant $R$. The arguments for the latter table are spaced at 10 wave number intervals from $100 \mathrm{~cm}^{-1}$ to $4000 \mathrm{~cm}^{-1}$.

Bibliography on atomic transition probabilities, B. M. Glennon and W. Wiese, NBS Mono. 50 (Aug. 1, 1962) 35 cents.

A bibliography on atomic transition probabilities is presented. The papers are arranged according to elements and stages of ionization, and the method employed and class of transitions are indicated behind each reference. Only articles on discrete transitions, both permitted and forbidden, are listed. Also included is a supplementary list of papers dealing with transition probabilities from a general point of view, a table showing the availability of numerical material on the individual atoms and ions, and a table of conversion factors.

Experimental transition probabilities for spectral lines of seventy elements, C. H. Corliss and W. R. Bozman, NBS Mono. 53 (July 20, 1962) \$4.25.

Relative intensities of 39,000 spectral lines with wavelengths between 2000 and 9000 angstroms have been determined on a uniform energy scale for seventy elements. The light source was an arc between copper electrodes to which a single element was added in the ratio of one atom of element to 
1000 atoms of copper. The temperature of the arc was determined, by comparison of the observed intensities with published relative $g f$-values, to be $5100 \pm 110^{\circ} \mathrm{K}$. The degree of ionization of eleven elements in the arc was determined by comparison of intensities in spectra of neutral and ionized atoms with known absolute $g$-values. With the aid of Saha's ionization equation, the electron density in the are was iound to be $2.4 \times 10^{14} \mathrm{~cm}^{-3}$. The ionization of seventy elements separately added to the arc was then calculated with Saha's equation. A correction was made for diffusion of atoms from the arc stream. With this information, relative values of $g f$ on a uniform scale can be computed for the 25,000 lines which have been classified. By calibration with known absolute $g f$-values, the scale is put on an absolute basis. Absolute transition probabilities for 25,000 lines of 112 spectra have been calculated in this way and the results are tabulated by spectrum. The wavelength in angstroms, energy levels to the nearest kayser, $g \mathrm{~A}$ in $10^{\circ}$ per second, $g f$, and the $\log g f$ are given for each line.

Systems of electrical units, F. B. Silsbee, NBS Mono. 56 (Sept. 20, 1952) 30 cents.

The various systems of measurement, with their respective sets of units, used in the literature on electricity and magnetism are described in detail. Their historical development is summarized. The manner in which each is derived from either of the two alternative points of view of the experimentalist and the theoretician is compared and contrasted. The desirability of recognizing both points of view in international standardization, particularly when discussing rationalization, is pointed out. The present status of the absolute measurements on which all electrical units are based is reported, and tables are included for the conversion of equations and numerical values from one system to another.

A tabulation of the thermodynamic properties of normal hydrogen from low temperatures to $540{ }^{\circ} \mathrm{R}$ and from 10 to 1500 psia, Supplement A (British units), J. W. Dean, NBS Tech. Note 120A (June 1962) 45 cents.

Pressure, volume, temperature, internal energy, enthalpy, and entropy of normal hydrogen gas have been tabulated along isobars in $2{ }^{\circ} \mathrm{R}$ temperature steps. The range covered is from the saturation temperature to $540{ }^{\circ} \mathrm{R}$ and from a pressure of 10 to 1500 psia. The source of data is Research Paper 1932 of the National Bureau of Standards Journal Of Research. The method is described by which the data presented in Research Paper 1932 is reduced to properties directly useful for engineering calculations. A method is also described for estimating the effects of ortho-para compositions upon the tabulated properties.

Tabular values are presented in the dimensional units of the British system. The tabulations are also available in the dimensional units of the metric system as technical Note No. 120 .

The thermodynamic properties of helium from 3 to $300^{\circ} \mathrm{K}$ between 0.5 and 100 atmospheres, D. B. Mann, NBS Tech. Note 154 (Jan. 1962) 50 cents.

The specific volume, enthalpy, entropy, and internal energy values of helium are presented in tabular form as functions of pressure and temperature.

Data are tabulated in one degree Kelvin increments for forty isobars between 0.5 atmospheres and 100 atmospheres. A comparison with previously published data is made where applicable.

An expression is presented which represents the pressuredensity-temperature surface based on previously published data.

The tabulation is presented in the dimensional units of the metric system, but is also available in the dimensional units of the British system (Supplement A).

Photosensitized reaction between hydrogen $\left({ }^{2} \mathbf{P}\right)$ atoms and molecular nitrogen, I. Tanaka and J. R. MeNesby, J. Chem. Phys. 36, No. 12, 3170-8173 (June 15, 1962).

The reaction between $H\left({ }^{2} \mathrm{P}\right)$ atoms and molecular introgen has been studied. $\quad H\left({ }^{2} \mathrm{P}\right)$ atoms were produced by irradiating ground state $\mathrm{H}\left({ }^{2} \mathrm{~S}\right)$ atoms, generated in a microwave discharge, with Lyman alpha radiation at $1216 \AA$ (ca. $10^{14}-10^{15}$ quanta sec $\left.{ }^{-1}\right)$. The interaction of $H\left({ }^{2} \mathrm{P}\right)$ atoms with $\mathrm{N}_{2}$ produces ammonia but not hydrazine. Two alternative mechanisms of the primary reaction are proposed. The first involves transfer of electronic energy.

$$
\begin{gathered}
\mathrm{H}\left({ }^{2} \mathrm{P}\right)+\mathrm{N}_{2}\left({ }^{1} \Sigma^{+} \mathrm{g}\right) \rightarrow \mathrm{H}\left({ }^{2} \mathrm{~S}\right)+\mathrm{N}_{2} * \\
\mathrm{~N}_{2} * \rightarrow 2 \mathrm{~N}\left({ }^{4} \mathbf{S}\right)
\end{gathered}
$$

The second possibility is a chemical mechanism involving atom transfer.

$$
\mathrm{H}\left({ }^{2} \mathrm{P}\right)+\mathrm{N}_{2}\left({ }^{1} \Sigma^{+} \mathrm{g}\right) \rightarrow \mathrm{NH}\left({ }^{3} \pi_{\mathrm{i}}\right)+\mathrm{N}\left({ }^{4} \mathrm{~S}\right)
$$

Ammonia is formed either by reaction of $\mathrm{N}$ with $\mathrm{H}$ or by reaction of $\mathrm{NH}$ with $\mathrm{H}$ or $\mathrm{H}_{2}$.

Effect of particle size on low-temperature heat capacities, A. C. Victor, J. Chem. Phys. 36, No. 10, 2812-2813 (May 15, 1962)

A new model is proposed to account for the particle size effect in low temperature heat capacities. As a first approximation a continuum approach is used. The model gives excellent agreement with sodium chloride data. Moderate success is also obtained with magnesium oxide and beryllium oxide.

Effect of molecular oxygen on the emission spectra of atomic oxygen-acetylene flames, S. L. N. G. Krishnamachari and H. P. Broida, J. Chem. Phys, 34, 1709-1711 (1961).

Studies have been made of the emission (3000 to $6000 \mathrm{~A}$ ) obtained from low pressure atomic oxygen-acetylene flames diluted with varying amounts of molecular oxygen and molecular nitrogen. Added molecular oxygen greatly increased the $\mathrm{OH}$ emission while reducing $\mathrm{CH}$ and $\mathrm{C}_{2}$ emission. It also had an effect on the rotational intensity distribution of $\mathrm{OH}$ and on the vibrational intensity distribution of $\mathrm{C}_{2}$. Nitrogen addition greatly reduced the rotational and vibrational "temperatures" and decreased $\mathrm{C}_{2}$ emission relative to the other emitters.

The structure of the vibrational-rotational bands of an asymmetric rotor, H. C. Allen, Jr., Phil. Trans. Roy. Soc. London, Ser. B. Math. and Phys. Sci. 253, No. 1030, 335-357 (Apr. 2\%, 1961).

The structure of A- and C-type vibrational-rotational bands of an asymmetric rotor is related to the band types of the two limiting symmetric rotors. The effect of the degree of asymmetry and the change in the effective inertial constants between the two vibrational states on the band structure is shown. The type of information which can be obtained from the analysis of these two types of band is pointed out.

Real representations of coordinate rotations, U. Fano, J. Math. Phys. 1, No. 5, 417-423 (Sept.-Oct. 1960).

Since irreducible tensorial sets that represent observables are of integral degree, their transformations under coordinate rotations have real representations. Real representations, with rows and columns classified by eigenvalues of the commuting operators $J_{z}{ }^{2}$ and $\exp \left(i \pi J_{y}\right)$, are given explicitly, so that complex functions of rotation angles need not be used. The addition of angular momenta is worked out for sets in the real representation such as the sets of real orbital wave functions. Applications to the theory of angular distributions are discussed.

Structural and internal state variables in the description of scalar rate processes in fluids, R. E. Nettleton, Phys. Fluids 4, 1488 (1961).

Arguments are presented to show that the internal energy per molecule in a macroscopically small volume element of an infinite liquid should remain constant, in first approximation, during a sudden fluctuation in liquid structure at constant density and temperature. This result is shown to be consistent with a formulation of non-equilibrium thermodynamies in which the departures of structural parameters from their local equilibrium values appear as thermodvnamic variables and in which there is no relaxing structural specific heat. However, it is shown that such a relaxing specific 
heat must appear in the thermodynamic treatment of thermal variables, which give the populations of internal vibrationalrotational states; and a new non-equilibrium thermodvnamics of thermal relaxation, extending the earlier work of Meixner to include inertial effects, is formulated in such a way as to be consistent with this fact. The new formulation, which replaces a previous theory now shown to be valid only for structural variables, is based on the Pauli equation, generalized to include second-order time-derivatives. It is shown, on plausible assumptions about the molecular transition probabilities, that one can calculate all the rate constants and relaxation times introduced to describe inertial effects, as well as the thermodynamic forces.

Quantum-mechanical calculation of harmonic oscillator transition probabilities in a one-dimensional impulsive collision, K. E. Shuler and R. W. Zwanzig, J. Chem. Phys. 33, No. 6, 1778-1784 (Dec. 1960).

The quantum mechanical vibrational transition probabilities $\mathrm{P}_{\mathrm{i} \rightarrow \mathrm{f}}(\epsilon)$ for harmonic oscillators, undergoing impulsive hard sphere collisions along the line of centers with an incident atom with relative kinetic energy $\epsilon$, have been computed by a machine (IBM-704) solution of the relevant Schrödinger equation. Curves for $\mathrm{P}_{\mathrm{i} \rightarrow \mathrm{f}}(\epsilon)$ over a range of $\epsilon$ are presented for initial (i) and final (f) vibrational oscillator states $i, f=0$, 1,2 and 3 . It is shown that this model of an inelastic collision gives rise to appreciable vibrational transitions $v(\mathrm{i}) \rightarrow v$ (f) with $|\Delta v|>1$ (in addition to the $|\Delta v|=1$ transitions) in contrast to the Landau-Teller-Herzfeld adiabatic, 1st order perturbation treatment which permits only transitions for which $|\Delta v|=1$. The implication of this result is discussed in relation to the dissociation of diatomic molecules and to the adsorption of atoms on solids. Averaged transition probabilities $\overline{\mathrm{P}}_{\mathrm{i} \rightarrow \mathrm{f}}(\mathrm{T})$ are computed for an incident beam of particles with a Maxwellian velocity distribution. It is pointed out that such averaged transition probabilities may give a misleading impression of the efficiency of translationalvibrational energy transfer if the $\mathrm{P}_{i \rightarrow f}(\epsilon)$ show a resonance type of behavior, i.e. a strong order of magnitude dependence of $\mathrm{P}_{\mathrm{i} \rightarrow \mathrm{f}}(\epsilon)$ on $\epsilon$ over a small interval of $\epsilon$.

The vapor pressure of $20^{\circ} \mathrm{K}$ equilibrium hydrogen, L. C. Weber, Jr., D. E. Diller, H. M. Roder, and R. D. Goodwin, Cryogenics 3, 236-238 (June 1962).

The vapor pressure of $20^{\circ} \mathrm{K}$ equilibrium hydrogen has been measured between the normal boiling point and the critical point. The data are represented analytically for purposes of smoothing and interpolation, and the results are compared with earlier work.

The densities of saturated liquid hydrogen, R. D. Goodwin, D. E. Diller, H. M. Roder, and L. A. Weber, Cryogenics $\mathbf{2}$, 81-83 (Dec. 1961).

Densities of para hydrogen from $17^{\circ}$ to $32^{\circ} \mathrm{K}$ are obtained by extrapolating newly determined compressed liquid isotherms to corresponding vapor pressures. Results are combined with earlier data for the range $14^{\circ}$ to $20^{\circ} \mathrm{K}$ and compared with normal hydrogen by means of density-temperature relationships.

Reference tables for $40 \%$ iridium-60\% rhodium versus iridium thermocouples, G. F. Blackburn and F. R. Caldwell, Book, Temperature, Its Measurement and Control in Science and Industry 3, Pt. 2, 151-175 (Reinhold Publ. Corp., New York, N.Y., 1962).

In a program to establish reference tables for several alloys of iridium and rhodium against iridium, the work has been completed on $40 \%$ iridium-60\% rhodium. Tables have been prepared giving emfs for temperatures in degrees Fahrenheit from $32{ }^{\circ} \mathrm{F}$ to $3800{ }^{\circ} \mathrm{F}$ and in degrees Celsius (centigrade) from $0{ }^{\circ} \mathrm{C}$ to $2100{ }^{\circ} \mathrm{C}$, and temperatures in these units with emf in millivolts as the argument. They are based on the average emfs measured on eight thermocouples, made from three lots of wire obtained in 1955,1958 and 1960.

Measurements at temperatures $32{ }^{\circ} \mathrm{F}$ to $2500{ }^{\circ} \mathrm{F}$ were made in a platinum-wound furnace of conventional design, using a $\mathrm{Pt}-10 \% \mathrm{Rh}$ vs Pt thermocouple to measure temperature. From $1950{ }^{\circ} \mathrm{F}$ to $3800{ }^{\circ} \mathrm{F}$ (thus overlapping the upper end of the lower range), the furnace used was an iridium block heated by electric induction. Blackbody conditions prevailed in the cavity in which the test thermocouple was inserted, and enabled measurement of the temperature with an optical pyrometer.

Rate of vaporization of refractory substances, J. J. Diamond, J. Efimenko, R. F. Hampson, and R. F. Walker, (Proc. 4th Intern. Symp. Reactivity of Solids), Book, Reactivity of Solids, ed., J. H. de Bower et al., p. 725 (Elsevier Publ. Co., Amsterdam, The Netherlands, 1961).

The more important factors affecting the rate of vaporization of solid systems are summarized. Techniques for measuring the rates of vaporization of refractory substances at temperatures in the $1600-3000{ }^{\circ} \mathrm{C}$ range are briefly described. The techniques pertain to measurements both in vacuum and in the presence of foreign gases. Some of the factors and the experimental techniques are illustrated by brief reference to studies of the vaporization of platinum and aluminum oxide.

Young's modulus of single crystal corundum from $77{ }^{\circ} \mathrm{K}$ to $850{ }^{\circ} \mathbf{K}$, J. B. Wachtman, Jr., W. E. Tefft, and D. G. Lam, Jr., Book, Mechanical Properties of Enqineering Ceramics, p. 221223 (Interscience Publ. Inc., New York N.Y., 1961).

An equation is proposed to represent the temperature dependence of Young's modulus. This equation fits data on some corundum single crystals very well.

The dynamic compressibility of a rubber-sulfur vulcanizate and its relation to free volume, J. E. McKinney, H. V. Belcher, and R. S. Marvin, Trans. Soc. Rheology 4, 347-362 (1960).

The dynamic bulk compliance of natural rubber $=12 \%$ sulfur was measured for varying static pressure (0 to 1000 bar), temperature $\left(-30\right.$ to $\left.+70{ }^{\circ} \mathrm{C}\right)$, and frequency $(50$ to 1000 cps). The data can be represented by reduced frequency or temperature plots, assuming viscosity is proportional to exp $(1 / \varphi)$, a fractional free volume which is a linear function of temperature and pressure. The temperature-frequency reduction fits the "universal" WLF constants, and the temperature-pressure reduction term is practically the same as that found by Singh and Holle for polyisobutylene.

Absorption spectrum of $\mathrm{CF}_{2}$ trapped in an argon matrix, A. M. Bass and D. E. Mann, J. Chem. Phys. 36, No. 12, 3501-3502 (June 15, 1962).

The products of a discharge through a mixture of $\mathrm{C}_{4} \mathrm{~F}_{8}$ and argon were condensed on a liquid-helium cooled surface. The absorption spectrum of the condensate shows a series of broad bands in the region 2300 to $2700 \mathrm{~A}$, and appears to correspond to the spectrum of the $\mathrm{CF}_{2}$ radical.

Thermocouple materials, F. R. Caldwell, Book, Temperature, Its Measurement and Control in Science and Industry 3, Pt. 2, 81-134 (Reinhold Publ., Corp., New York, N.Y., 1962).

Thermocouple materials are considered that are used primarily as immersion temperature sensors in the range from $0{ }^{\circ} \mathrm{C}$ up. Included are the conventional thermocouples that have survived since the beginnings of the art of thermoelectric temperature measurement, newer noble metal thermocouples, and thermocouples of refractory metals for use in the extreme range for immersed sensors. Because of the wide use and increasing popularity of ceramic-packed thermocouples in metal sheaths, they are included.

Limitations of the thermocouple wires are given as to range, stability, environment included atmosphere, magnitude of thermoelectric emf, and accuracy of commercially available materials of standard and extra quality. In addition, properties of the separate elements that are pertinent to the selection or use of thermocouples have been compiled.

In the case of the ceramic-packed thermocouples the following properties are presented: temperature range of the sheath, mechanical properties of the sheath, kinds of packed insulation, resistance between thermocouple wires and between wires and sheath, minimum bending radius of the packed stock, gas-tightness of the packed insulation, and types of measuring junctions available, i.e. grounded, ungrounded, bare, totally enclosed. stagnation mounting, etc. 
Thermal radiation standards and measurements of the Radiometry Section at the National Bureau of Standards, A. G. Maki, (Proc. conf. Radiative Transfer from Solid Materials, Boston, Mass., Dec. 12-13, 1960), Book, Radiative Transfer from Solid Materials, ed., H. H. Blau, Jr., and $H$. Fischer, Sec. III, p. 135-141 (The Macmillan Co., New York, N.Y., 1962).

A discussion was given of two aspects of the work of the Radiometry Section at the National Bureau of Standards. Two standards of thermal radiation were described and the method of their calibration detailed. The latter half of this paper will include a description of some work currently being carried on with the aim of obtaining the normal spectral emissivity of gold, aluminum, and platinum in the infrared.

The ammonia beam maser as a standard of frequency, J. A. Barnes, D. W. Allan, and A. E. Wainwright, IRE Trans. Instrumentation I-11, 26-30 (June 1962).

It has been suggested that an error in tuning of the resonant cavity in an ammonia beam maser could be detected by observing a frequency shift of the maser with the application of a magnetic field. Following this suggestion, an oscillatory magnetic field was applied to the NBS double beam maser and a low noise phase demodulator was constructed to detect any phase modulation present in the maser signal. With this equipment, a servo-loop was completed to constantly control the tuning of the maser's resonant cavity. Not only did this result in the elimination of the most critical parameter of the maser's frequency dependence, but improvement of the frequency dependence upon other parameters was also observed.

The radiative formation and destruction of negative ions, L. M. Branscomb, Proc. Fifth Intern .Conf. Ionization Phenomena in Gases, Munich, Germany, I, 1-18 (North Holland Publ. Co., Amsterdam, The Netherlands, 1961)

Recent advances in our understanding of the formation and destruction of negative ions by radiative processes are reviewed. Photodetachment spectra of four atomic ions, $\mathrm{H}^{-}$, $\mathrm{O}^{-}, \mathrm{S}^{-}$and $\mathrm{C}^{-}$have been studied experimentally in crossed beams. Agreement between theory and experiment on $\mathrm{H}^{-}$ is now excellent, except in the threshold region, where the theoretical values are about $10 \%$ low, presumably because of neglect of polarization effects. The $\mathrm{C}^{-}$spectrum is consistent with that expected for a $\mathrm{C}^{-4} \mathrm{~S}$ ground state, about $1.25 \mathrm{ev}$ below the continuum, and a weakly bound metastable (presumably ${ }^{2} \mathrm{D}$ ) state which gives rise to a weak absorption on the infrared side of the 1.25 volt threshold. Metastable states of other atomic ions are predicted. Radiative attachment cross sections and rate coefficients are discussed. The difficulties in interpretation of molecular photodetachment spectra are emphasized.

Group theory and crystal field theory, C. M. Herzfeld and P. H. E. Meijer, Book, Solid State Physics 12, 1-91 (Academic Press, Inc., New York, N.Y., 1961).

A survey of the principal group theoretical principles and methods used in crystal field theory.

Ferroelectricity in the compound $\mathbf{B i}_{4} \mathbf{T i}_{3} \mathbf{O}_{12}$ P. H. Fang and C. R. Robbins, Phys. Rev. 126, No. 3, 892 (May 1962).

Some ferroelectric and crystallographical properties of the compound $\mathrm{Bi}_{4} \mathrm{Ti}_{3} \mathrm{O}_{12}$ are presented. The compound has a dielectric maximum at $685^{\circ} \mathrm{C}$ on increasing temperature and at $670^{\circ} \mathrm{C}$ on decreasing temperature. At these temperatures, temperatures, an endothermic peak and an exothermic peak, respectively, occur. Ferroelectricity was observed along the $c$ axis of the single crystal of this compound.

Linear thermal expansion of aluminum oxide and thorium oxide from $100^{\circ}$ to $1100^{\circ} \mathbf{K}$, J. B. Wachtman, Jr., T. G. Scuderi, and G. W. Cleek, J. Am. Ceram. Soc. 45, 310-323 (July 1962).

The linear thermal expansion of single crystal and polycrystalline aluminum oxide and polycrystalline thorium oxide was measured from $100^{\circ}$ to $1100^{\circ} \mathrm{K}$ with an interferometric technique. For each substance the results are well described by Grüneisen's equation using a Nernst-Lindemann energy function.
Dielectric loss in "non-polar" polymers, A. J. Curtis, J. Chem. Phys. 36, No. 12, 3500 (June 15, 1962).

Using published values of dipole moments of some saturated hydrocarbons, obtained from microwave spectroscopy, we have shown that the dielectric dispersion and loss observed in hydrocarbon polymers may be reasonably accounted for in large part in terms of asymmetry in structure. These calculations show that it is not necessary to propose impurities, oxidation products such as carbonyl groups, or catalyst fragments to account for much of the dielectric relaxation in these materials. These calculations also predict considerably lower dielectric loss in a completely linear polymer such as polyethylene than in a branched material such as polypropylene.

Mobilities of positive ions in argon, E. C. Beaty, Proc. Conf. Ionization Phenomena in Gases, Aug. 28-Sept. 1, 1981, Munich, Germany, p. 183 (North Holland Publ. Co., Amsterdam, The Netherlands, 1962).

Ions of three different mobilities are observed in the afterglow of a pulsed discharge in pure argon. The low field mobilities are: $1.535 . \pm 007,1.833 \pm .008,2.60 \pm .02\left(\mathrm{~cm}^{2}\right.$ volt $\left.^{-1} \mathrm{sec}^{-1}\right)$. The lowest value is associated with $\mathrm{A}^{+}$. The identities of the other two are uncertain; however, semi-quantitative data are presented which indicate that each of the three are argon ions and are not the products of charge exchange with a contaminant. The ion of intermediate mobility was called $\mathrm{A}^{+}$ by Munson and Tyndall, and $\mathrm{A}_{2}{ }^{+}$by Hornbeck. The fastest ion was called $\mathrm{A}_{2}+$ by Biondi and Chanin.

Infrared spectrum of dideuteroacetylene $\left(\mathrm{C}_{2} \mathrm{D}_{2}\right), \mathrm{E} . \mathrm{D}$. Tidwell and E. K. Plyler, J. Opt. Soc. Am. 52, No. 6, 656-664 (June 1962).

Thirty bands of $\mathrm{C}_{2} \mathrm{D}_{2}$ have been observed and measured between 1900 and $3300 \mathrm{~cm}^{-1}$. Twenty of these have been resolved well enough to permit extraction of rotational constants. The $\Delta_{2} \mathrm{~F}$ values up to J35 for three $\Sigma_{g}$ ground state bands were averaged and correlated with other data for a more reliable $\mathrm{B}_{0}=0.84794+0.00005$ and $\mathrm{D}_{0}=7.85 \times 10^{-7}+$ $0.4 \times 10^{-7}$ where the indicated uncertainties are the probable errors of the coefficients. Better resolution and higher $J$ values have reduced the uncertainty derived from other sources. The l-type doubling constants for $\mathrm{v}_{4}^{1}$ and $\mathrm{v}_{5}^{1}$ have been obtained from resolved $\mathrm{Q}$ branches and split $\mathrm{P}$ and $\mathrm{R}$ branches; they are $\mathrm{q}_{4}=.00316 \mathrm{~cm}^{-1}$ and $\mathrm{q}_{5}=.00314 \mathrm{~cm}^{-1}$.

\section{Other NBS Publications}

Journal of Research 66B (Math. and Math. Phys.), No. 4 (Oct.-Dec. 1962), 75 cents.

Reliability of a system in which spare parts deteriorate in storage. G. H. Weiss. (See above abstracts.)

Estimation of dispersion parameters. W. A. Thompson, Jr.

Laguerre expansions for successive generations of a renewal process. G. H. Weiss. (See above abstracts.)

Bounds on ratios of means. G. T. Cargo and O. Shisha.

A model for the viscoelastic behavior of rubberlike polymers including entanglement effects. R. S. Marvin and H. Oser.

Black box maximization of circular coverage. C. T. Zahn, Jr. An application of information theory to the analysis of contingency tables, with a table of $2 n 1 n n, n=1$ (1) 10,000 . S. Kullback, M. Kupperman, and H. H. Ku. See above abstracts.)

Journal of Research 67D (Radio Prop.), No. 1 (Jan.-Feb. 1963), 70 cents.

A lunar theory reasserted - a rebuttal J. V. Evans.

Point-to-point communication on the moon. L. E. Vogler. HF communication during ionospheric storms. G. E. Hill. Use of surface refractivity in the empirical prediction of total atmospheric refraction. W. R. Iliff and J. M. Holt. (See above abstracts.)

Effective sunspot numbers. W. B. Chadwick.

On the theory of radio wave propagation over inhomogeneous earth. K. Furutsu.

Fields of electric dipoles in sea water (a correction). W. Anderson.

Composition of reflection and transmission formulae. J. Heading. (See above abstracts.) 
Titheridge coefficients for the polynomial method of deducing electron density profiles from ionograms. A. R. Long and J. O. Thomas. (See above abstracts.)

Input admittance of linear antennas driven from a coaxial line. T. T. Wu.

A survey of the techniques for measuring the radio refractive index, R. E. McGavin, NBS Tech. Note 99 (May 1962), 30 cents.

Required signal-to-noise ratios, RF signal power, and bandwidth for multichannel radio communications systems, E. F. Florman and J. J. Tary, NBS Tech. Note 100 (Jan. $1962), \$ 1.00$.

Mode conversion in the earth-ionosphere waveguide, J. R. Wait, NBS Tech. Note 151 (June 8, 1962) 20 cents.

A general survey of the semiconductor field, G. W. Reimherr, NBS Tech. Note 153 (Aug. 1962) 30 cents.

Information selection systems retrieving replica copies: A state-of-the-art report, T. C. Bagg and M. E. Stevens, NBS Tech. Note 157 (Dec. 31, 1961) \$1.25.

Efficient use of the radio spectrum, K. A. Norton, NBS Tech. Note 158 (Apr. 1962) 45 cents.

A Fortran code for calculation of eigenvalues and eigenfunctions in real potential wells, R. S. Casewell, NBS Tech. Note 159 (August 1962) 25 cents.

A procedure for estimating eigenvalues, N. W. Bazley and D. Fox, J. Math. Phys. 3, 469-471 (May-June 1962).

Physical standards of emittance and reflectance, J. C. Richmond, (Proc. Conf. Radiative Transfer from Solid Materials, Boston, Mass., Dec. 12-13, 1960), Book, Radiative Transfer from Solid Materials, ed. H. H. Blau, Jr., and H. Fischer, Sec. III, p. 142-153 (The Macmillan Co., New York, N.Y., 1962).

Tchebycheff approximations by exponentials, J. R. Rice, J. Soc. Ind. Appl. Math. 10, No. 1, 149-161 (Mar. 1962).

Signs of nuclear resonance coupling constants in saturated aliphatic systems, H. Finegold, Proc. Chem. Soc. p. 213-214 (June 1962).

The morphology of mid-latitude 6300 angstrom ares, $\mathrm{T}$ Tohmatsu and F. E. Roach, J. Geophys. Res. 6\%, No. 5, 1817-1821 (May 1962).

Some electrical properties of the porous graphite contact on p-type silicon, G. G. Harman, T. H. Higier, and O. L. Meyer, J. Appl. Phys. 38, 2206 (July 1962).

A combined analog-digital differential analyzer (CADDA), W. D. Urban, W. R. Hahn, Jr., and H. K. Skramstad, Proc. Combined Analog Digital Computer Systems Symp., Phila., Pa., Dec. 1960, 2d item (1960).

The types of blackout, their time variations, and the mechanisms producing them, V. Agy, J. Phys. Soc. Japan 1\%, 93-97 (Sept. 1961).

Some properties of dirty contacts on semi-conductors and resistivity measurements by a two terminal method, G. G. Harman and T. Higier, J. Appl. Phys. 33, 2198 (July 962 ).

A property of linear frequency modulation, A. J. Goldman, Proe. IRE 50, No. 7, 1711 (July 1962).

Programming for a closed-loop manned-machine combined system, D. C. Friedman, Proc. Combined Analog Digital Computer Systems Symp., Phila., Pa., Dec. 1960, 12th item (1960)

Studies in non-equilibrium rate processes. V. The relaxation of moments derived from a master equation, K. E. Shuler, K. Anderson, and G. H. Weiss, J. Math. Phys. 3, No. 3, 550-556 (Mav-June 1962)

The thermal properties of powder insulators in the temperature range $300^{\circ}-4{ }^{\circ} \mathrm{K}, \mathrm{D}$. Cline and $\mathrm{R}$. H. Kropschot (Proc. Conf. Radiative Transfer from Solid Materials, Boston, Mass., Dec. 12-13, 1960), Book, Radiative Transfer from Solid Materials, ed. H. H. Blau, Jr., and H. Fischer, Sec. I, p. 61-81 (The Macmillan Co., New York, 1962).

Kinetics of the hydrolysis of acetal in N-methylpropionamidewater and $\mathrm{N}, \mathrm{n}$-dimethylformamide-water solvents at 20 , 25,30 , and $40^{\circ}$, R. K. Wolford and R. G. Bates, J. Phys. Chem. 66, No. 8, 1496-1500 (1962).

Symposium on spectroscopic excitation, B. F. Scribner, Am. Soc. Testing Materials Spec. Tech. Publ. 259, 1 (Oct. 1960).
Path loss measurements versus prediction for long distance tropospheric scatter circuits, A. F. Barghausen and C. F. Peterson, IRE Trans. Commun. Systems CS-9, No. 4, 439-445 (Dec. 1961).

Introduction to the theory of V.L.F. propagation, J. R. Wait, Proc. IRE 50, 1624-1647 (July 1962)

Some experimental aspects of nuclear orientation, E. Ambler, Proc. Tenth Intern. Congress of Refrigeration, Copenhagen, Denmark, I, 195-198 (1959).

The cement reference laboratory (1929-1959), J. R. Dise, Am. Soc. Testing Materials Proc. 59, 369 (1959).

International coordination of measurement, A. G. MeNish, MeNish, Sci. Math. Weekly 2, No. 3, 28-29 \& 35 (Sept. 1961).

The calibration at the National Bureau of Standards of mass standards for ultramicroanalysis, L. B. Macurdy, Book, Vacuum Microbalance Techniques, ed. R. F. Walker, 2, 165-175 (Plenum Press, Inc., New York, N.Y., 1962).

Post office mechanization, B. M. Levin, M. C. Stark and P. C. Tosini, Elec. Eng. 80, No. 2, 105-110 (Feb. 1961).

Irreversible processes in liquids and the density matrix: monatomic molecules, R. E. Nettleton, Phys. Fluids 5, No. 6, 687-700 (June 1962).

Switching properties in ferroelectries of the family $\mathrm{Bi}_{4} \mathrm{Ba}_{m-2} \mathrm{Ti}_{m+1} \mathrm{O}_{3(\mathrm{~m}+2)}$, P. H. Fang and E. Fatuzzo, J. Phys. Soc. Japan 1\%, 238 (1962).

A derivation of the relaxation spectrum representation of the mechanical response function, R. S. Marvin, Repts. Progr. Polymer Phys. Japan 5, 56-58 (1962)

Thermal isomerization of isopropvl-1,1,1- $\mathrm{d}_{3}$ radicals, W. M. Jackson and J. R. MeNesby, J. Chem. Phys. 36, No. 9, 2272-2275 (May 1, 1962).

Research on light metals in the Metallurgy Division, National Bureau of Standards, T. G. Digges, (Symp. Light Metal Industry, Jamshedpur, India) Indian Construction News, p. 68 (Aug. 1961)

A nomograph for selecting light balancing filters for camera exposure of color films, C. S. McCamy, Med. Biol. Illustration, London, England 11, No. 1, 13-15 (Jan. 1961).

Attempts to eliminate fatigue damage by heat treatment, J. A. Bennett, Am. Soc. Metals, Trans. Quart. (Tech. Notes) 55. No. 2, 362-363 (June 1962). Graphs for bivariate normal probabilities, M. Zelen and N. C. Severo, Ann. Math. Stat. 31, No. 3, 619-624 (Sept. 1960)

A controller for maintaining a constant rate of vaporization in fractional distillation, E. C. Kuehner and R. T. Leslie, Anal. Chem. 34, No. 9, 1155-1156 (Aug. 1962).

Nuclear moment of NI ${ }^{61}$, L. H. Bennett and R. L. Streever, Jr., Phys. Rev. Letters 121, No. 6, 2141-2142 (June 15, 1962).

A method for determining mechanical resonance frequencies and for calculating elastic moduli from these frequencies, S. Spinner and W. E. Tefft, Am. Soc. Testing Materials Proc. 61, 1221-1238 (1961).

New uses of microfilm with electronic scanners, a progress report on FOSDIC III, M. L. Greenough, Proc. 8th Annual Meeting Natl. Microfilm Assoc., Wash. D.C. Apr. 2-4, 1959, p. 278 (Annapolis, Md., 1959)

Susceptor elements for high temperature induction heating, S. Hasko and H. S. Parker, Am. Ceram. Soc. Bull. 41, No. 7, 467 (July 1962).

Relation of solar active regions at central meridian passage to ionospheric disturbance, C. S. Warwick and J. V. Lincoln, AGARDograph Proc. Sixth AGARD Ionospheric Research Committee Meeting (Rome, Italy, May 15-18, 1961).

Suggested arrangement of mirrors to form multiple reference angles, J. B. Saunders, J. Opt. Soc. Am. 51, No. 8, 859-862 (Aug. 1961).

Radiolysis of ethane-1,1,1-d $\mathrm{d}_{3}$, L. J. Stief and P. Ausloos, J. Chem. Phys. 36, No. 11, 2904 (June 1, 1962).

D-C differential current meter, E. Niesen, Rev. Sci. Instr. 32, No. 12, 1407-1408 (Dec. 1961).

Radiowave propagation during world war II, K. L. Norton, Proc. IRE 50, No. 5, 698-704 (May 1962).

Development directions to keep leather apace, J. R. Kanagy, Leather \& Shoes 142, 34-35 (Aug. 12, 1961).

High-energy X-ray spectrometer using large anticoincidence sodium iodide crystals, J. M. Wycoff, Proc. Total Absorp- 
tion Gamma-Ray Spectrometry Symp., Gatlinburg, Tenn., May 10, 1960, p. 201-210 (1960).

Radio propagation quality in the North Atlantic area 19531960, M. E. Nason, AGARDograph Proc. 6th AGARD Ionospheric Research Committee Meeting (Rome, Italy, May $15-18,1961)$.

Discussion of Feldman's and Sereda's Paper "Characteristics of sorption and expansion isotherms of reactive limestone aggregate," C. M. Hunt, L. A. Tomes, R. G. Pike, and D. Hubbard, J. Am. Concrete Inst. 59, 815-818 (Mar. $1962)$.

The National Bureau of Standards Library, S. A. Jones, D. C. Libraries 32, 7-10 (Jan. 1961)

Systematic errors, W. J. Youden, Ordnance XLVI, No. 248, 299-301 (Sept.-Oct. 1961).

Determination of the dissociation equilibria of water by a conductance method, H. C. Duecker and W. Haller, J. Phys. Chem. 66, No. 2, 225-229 (Feb. 1962).

Heat of formation of the most stable form of metaboric acid, $\mathrm{HBO}_{2}(\mathrm{c}, \mathrm{I})$, M. V. Kilday and E. J. Prosen, J. Am. Chem. Soc. Commun. to Editor 82, 550 (1960).

The scientific contributions of William Weber Coblentz, E. K. Plyler, J. Appl. Spect. 16, No. 3, 73-77 (1962). The rapid selector and other NBS document retrieval studies, J. L. Pike and T. C. Bagg, Proc. National Microfilm Assoc.. Annual Meeting, Wash. D. C., Apr. 25-27, 1962, XI, 213-227 (Annapolis, Md., 1962).

1 test method for air-entrainment of standard Ottawa sand, M. R. DeFore and H. J. Corah, ASTM Bull. No. 248, 48-56 (TP162-166) (Sept. 1960).

The angular distribution of beta particles from oriented cerium- 141 nuclei, D. D. Hoppes, Proc. Seventh Inter. Conf. Low Temperature Physics, University of Toronto, Canada, Aug. 1960, p. 186 (University of Toronto Press, Toronto, Canada, 1960)

Die radiometeorologie and ihre bedeutung fur die ausbreitung der $\mathrm{m}-$, dm- and $\mathrm{cm}$ - wallen auf grosse entfernungen, B. R. Bean, L. Fehlhaber, and J. Grosskopf, Nachr. Z (NTZ), p. 9-16 (Jan. 1962).

The program at the National Bureau of Standards, L. M. Branscomb, Book, Optical Spectroscopic Measurements High Temperatures, ed. P. J. Dickerman, p. 235 (Univ. of Chicago Press, Chicago, Ill. 1961).

Determination of oxidation rates of air-blown asphalts by infrared spectroscopy, J. R. Wright and P. G. Campbell. J. Appl. Chem. 12, 256-266 (June 1962)

Study of "valley problem" with a ray tracing program, $\mathrm{K}$. Davies and A. K. Saha, Electron Density Profiles, p. $162-$ 166 (1962)

The extrapolation of the orthorhombic N-paraffin melting properties to very long chain lengths, M. G. Broadhurst, J. Chem. Phys. 36, No. 10, 2578 (May 15, 1962).

An equation of state for calculating the thermodynamic properties of helium at low temperatures, R. D. McCarty and R. B. Stewart, Book, Progress in International Research on Thermodynamic and Transport Properties, p. 107-117 (Academic Press, Inc., New York, N.Y., 1962).

Oscillatory phenomena, A. H. Kahn (Proc. Conf. High Magnetic Field, Mass. Inst. Tech. Cambridge, Mass., Nov. 1-4, 1961), Book, High magnetic fields, p. 480-488 (Mass. Inst. Tech. Press, Cambridge, Mass., and John Wiley and Sons, Inc., New York, N.Y., 1962)

Thermal expansion of some engineering materials from $20^{\circ} \mathrm{K}$ to $293^{\circ} \mathrm{K}, \mathrm{V}$. Arp, J. H. Wilson, L. Winrich, and P. Sikora, Crvogenies 3, 230 (June 1962).

Interlaboratory evaluation of a method for indicated brightness of papers containing fluorescent brighteners, T. W Lashof and J. M. Patek, Tappi 45, No. 7, 566 (July 1962).

An intermediate size automatically controlled hydrogen refrigeration system, D. B. Chelton, D. B. Mann, and B. W. Birmingham, Suppl. Bull. Inst. Intern du Froid, Eindhoven, Comm. 1, Annexe 1960-61, 169-178 (1960)

Absolute microwave refractometer, M. J. Vetter and M. C. Thompson, Jr., Rev. Sei. Instr. 33, 656-660 (June 1962).

The information problem in government, S. N. Alexander, Proc. Engineering Information Symp. (Sponsored by the Engineers Joint Council), p. 15-16 (Jan. 17, 1962).

Problems in the temperature calibration of an X-ray diffractometer furnace, F. A. Mauer and L. H. Bolz, (Proc.
Tenth Annual Conf. Applications of X-ray Analysis, Denver, Colo., Aug. 7-9, 1961), Book, Advances in Xray analysis, p. 229 (Plenum Press, Inc., New York, N.Y. 1962).

The detection and study of solar cosmic ravs by radio techniques, D. K. Bailey, (Intern. Conf. on Cosmic Rays and the Earth Storm), J. Phys. Soc. Japan 1\%, Suppl. A-1, Pt. I, 106-112 (1962).

Precision and accuracy-experiment design aspects, C. Eisenhart, Conf. on Applications of Statistical Methods in the Chemical Industry, Feb. 4, 1961, (Sponsored by Am. Soc. for Quality Control, Metropolitan Section, Seaton Hall University, South Orange, N.J.), p. (1961). Games associated with a renewal process, M. M. Siddiqui, Ann. Math. Stat. 33, 697-701 (June 1962).

Purification and vapor pressure of pure nitric oxide, E. E. Hughes, J. Chem. Phys. Letter to Editor 35, No. 4, 1531 1532 (Oct. 1961)

Ultrasounds induce flaking of ceramics from metals, J. W Pitts, Metal Progr. 82, No. 2, 114-115 (Aug. 1962).

Ferroelectricity in the compound $\mathrm{Ba}_{2} \mathrm{Bi}_{4} \mathrm{Ti}_{5} \mathrm{O}_{18}, \mathrm{P}$. H. Fang and B. Aurivillius, Phys. Rev. 126, No. 3, 893 (May 1962).

Use of gas phase chromatography for rapid determination of carbonate at low levels, F. G. Carpenter, Anal. Chem. 34, 66 (Jan. 1962)

An experimental investigation of the scintillation of radio stars observed at frequencies of 223 and 456 megacycles per second from a location close to the auroral zone, C. G. Little, G. C. Reid, E. Stiltner, and R. P. Merritt, J. Geophys. Res. 6\%, No. 5, 1763-1784 (Mav 1962)

A computer for weather data acquisition, P. Meissner, J. A. Cunningham, and C. A. Kettering, Proc. Eastern Joint Computer Conf., Dec. 13-15, 1960, p. 57 (New York, N.Y., 1960).

Position titles of chemists, W. K. Wilson, Capital Chemist 10, 145 (May 1960).

Corrected calculations of sound absorption in non-associated liquids, R. E. Nettleton, J. Acoust. Soc. Am. 34, No. 3, 350 (Mar. 1962).

International comparisons of radioactivity standards, W. E. Perry and W. B. Mann, Proc. Ninth Intern. Congress on Radiology, Munich, Germany, July 1959, 23, VII-30. VII, 1338-1342 (Urban and Schwarzenberg, Munich, Germany, 1960).

Criteria for the reality of matrix eigenvalues, M. P. Drazin and E. V. Haynsworth, Z. Math. 78, 449-452 (Mar. 1962).

A rapid simple method of estimating the order of chemical reactions, J. H. Flynn, Chem. Eng. 69, No. 17, 137-140 (Aug. 20, 1962).

Paramagnetic resonance phenomena, H. E. Radford, Encyclopaedic Dictionary of Physics 5, 293 (Pergamon Press Ine., New York, N.Y., 1962).

Chilled-air-distribution in refrigerated trailers, P. R. Achenbach, Suppl. Bull. Intern. Inst. of Refrigeration, p. 9 (1961-1962)

Mass spectrum and appearance potentials of tetrafluorohydrazine, J. T. Herron and V. H. Dibeler, J. Chem. Phys. 33, No. 5, 1595-1596 (Nov. 1960).

Large longitudinal retarded elastic deformation of rubberlike network polymers, H. Leaderman, J. Polymer Sci. 59, No. 168, S42 (June 1962)

A survey of polar cap absorption events (solar proton events) in the period 1952 through $1960, \mathrm{D}$. K. Bailey and J. M. Harrington, (Intern. Conf. on Cosmic Rays and the Earth Storm), J. Phys. Soc. Japan 17, Suppl. A-II, Pt. II, 334 337 (1962).

Magnifications of a telescope, R. E. Stephens, J. Opt. Soc. Am. 51, No. 7, 803-804 (July 1961).

Isotope effect in an electric field and jump frequencies for diffusion in ionic crystals, J. R. Manning, J. Appl. Phys. 333, No. 7, 2145-2151 (July 1962).

Determination of isotope effects by "double labeling" oxidation of d-glucose with iodine, H. S. Isbell, L. T. Sniegoski, and H. L. Frush, Anal. Chem. 34, No. 8, 982-984 (July 1962).

Methods of nuclear orientation, E. Ambler, Book, Progress in Cryogenics, ed., K. Mendelssohn III, 235-280 (Heywood and Co., Ltd., London, England, 1960). 
Molecular collision models and transition probabilities in liquids, R. E. Nettleton, J. Chem. Phys. 38, 2226-2227 (Apr. 1962).

Electronic development and production in the USSR, C. P. Marsden, Encylcopedia on Russia and the Soviet Union, p. 158-160 (McGraw-Hill Book Co., Inc., New York, N.Y., 1961)

Microwave spectrum of trimethylarsine, D. R. Lide, Jr., Spectrochem. Acta 15, 473 (1959).

Lattice frequencies and rotational barriers for inorganic carbonates and nitrates, R. A. Schroeder, C. E. Weir, and E. R. Lippincott, J. Chem. Phys. 36, No. 10, 2803-2804 (May 1962)

Environmental characteristics of a small underground fallout shelter, P. R. Achenbach, F. J. J. Drapeau, and C. W. Phillips, ASHRAE J. 4, No. 1, 21 (Jan. 1962).

Opportunities in dental research, G. C. Paffenbarger, J. Am. Dental Assoc. 60, No. 3, 413-414 (Mar. 1960).

On the nature of equatorial slant sporadic E, R. Cohen, K. L. Bowles and W. Calvert, J. Geophys. Res.6\%, No. 3, 965-972 (Mar. 1962).

Elementary statistical design, W. J. Youden, Conf. on Applications of Statistical Methods in the Chemical Industry, Feb. 4, 1961 (Sponsored by Am. Soc. for Quality Control, Metropolitan Section, Seaton Hall University, South Orange, N.J), p. 43 (1961).

Blue-glass filters to approximate the blackbody at $6500^{\circ} \mathrm{K}$, D. B. Judd, Farbe 10, No. 1-4, 31 (1961).

Correction to "doppler studies of the ionosphere with vertical incidence," K. Davies, Proc. IRE 50, No. 6, 94 (June 1962).

Electron photo-detachment from ions and elastic collision cross sections for $\mathrm{O}, \mathrm{C}, \mathrm{Cl}$ and F, J. W. Cooper and J. B. Martin, Phys. Rev. 126, No. 4, 1482 (May 15, 1962).

The following articles were presented before the 1961 Cryogenic Engineering Conference and published in the Book, Advances in Cryogenic Engineering $\boldsymbol{\gamma}$ (Plenum Press, Inc., New York, N.Y., 1962)

A crvostat for tensile tests in the temperature range $300^{\circ}$ to $4^{\circ}$ K, R. P. Reed, Paper K-3, 448-454.

A method of measuring shear modulus from $-424^{\circ}$ to $70^{\circ}$ F, R. P. Mikesell and R. M. McClintock, Paper $\mathrm{K}-11,509-513$.

An electrically controlled guarded flat plate calorimeter, D. Cline and R. H. Kropschot, Paper L-5, 534-538.

An experimental investigation of the individual boiling and condensing heat transfer coefficients for hydrogen, D. E. Draver and K. D. Timmerhaus, Paper J-6, 401-412.

Dry gas operation of ball bearings at cryogenic temperatures, L. E. Scott, D. B. Chelton, and J. A. Brennan, Paper G-3, 273-276.

Low temperature characteristics of some commercial thermocouples, R. L. Powell and L. P. Caywood, Jr., Paper L-2, 517-521.

Martensitic transformation products and mechanical properties of austenitic stainless steels at low temperatures, C. J. Guntner and R. P. Reed, Paper K-9, 500-502.

On the bulk density of boiling liquid oxygen, $R$. W . Arnett, Paper F-4, 214-218.

Temperature dependence of magnetic losses, J. J. Gniewek and R. L. Powell, Paper H-1, 303-310.

Testing of ball bearings with five different separator materials at 9200 RPM in liquid nitrogen, J. A. Brennan, W. A. Wilson, R. Radebaugh, and B. W. Birmingham, Paper G-2, 262-272.

The application and behavior of elastomers at eryogenic temperatures, R. F. Robbins, D. H. Weitzel, and R. N. Herring, Paper $\mathrm{H}-6,343-352$.

The application of gas-lubricated bearings to a miniature helium expansion turbine, B. W. Birmingham, H. Sixsmith, and W. A. Wilson, Paper A-4, 30-42.

The efficiency of an ideal refrigerator, R. B. Jacobs, Paper L-11, 567-571.

Application of reflectometer techniques to accurate reflection measurements in coaxial systems, R. W. Beatty and W. J. Anson, Proc. Inst. Elec. Engr. B, 109, 345-348 (July 1962).

Chemically induced vibrational excitation: Hydroxyl radical emission in the 1-3-micron region produced by the $\mathrm{H}+\mathrm{O}_{3}$ atomic flame, D. Garvin, H. P. Broida, and H. J. Kostkowski, J. Chem. Phys. 3\%, No. 1, 193 (July 1962).
Gas-phase radiolysis of propane, P. Ausloos and S. Lias, J. Chem. Phys. 36, No. 12, 3163-3170 (July 15, 1962).

Four methods for predicting the durability of roofing asphalts, S. H. Greenfeld and J. R. Wright, Mater. Res. Std. 2, No. 9, 738-745 (Sept. 1962).

The absolute simplest form in digital circuit design, R. S. Ledley, Book, Digital Computers and Control Engineering, 835 pgs., (McGraw-Hill Book Co., Ine., New York, N.Y., $1960)$.

Coring an electroform, W. H. Metzer, Jr., Plating 49, No. 8, 880 (Aug. 1962)

The standards challenge, A. H. Scott, Insulation 8, No. 2, 48-50 (Feb. 1962)

A system for generating "pronounceable" names using a computer, A. L. Leiner and W. W. Youden, J. Assoc. Computing Mach 8, No. 1, 97-103 (Jan. 1961).

Using digital computers in the design and maintenance of new computers, A. L. Leiner, A. Weinberger, H. Loberman, and C. Coleman, IRE Trans. Electronic Computers EC-10, No. 4, 680-690 (Dec. 1961).

Surface preparation of solid metallic samples for X-ray spectrochemical analysis, R. E. Michaelis and B. A. Kilday, Book, Advances in X-ray Analysis 5, 405-411 (Plenum Press, Inc., New York, N.Y., 1962).

Infrared wavelength dependence of the total absorptivity of electroplated silver, D. Cline, J. Appl. Phys. 33, 2310-2311 (July 1962).

Simple stain gauge-based load controller, L. Mordfin and R. L. Bloss, Rev. Sci. Instr. 33, No. 7, 772-773 (July 1962). Quantum-mechanical calculation of harmonic oscillator transition probabilities. II. Three-dimensional impulsive collisions, F. H. Mies and K. E. Shuler, J. Chem. Phys. 37, No. 1, 177-181 (July 1, 1962).

Remote phase control of station WWV, R. F. Fey, J. B. Milton, and A. H. Morgan, Nature 193, No. 4820, 1063 1064 (Mar. 17, 1962).

Melting and contractility of feather keratin, L. Mandelkern, J. C. Halpin, and A. F. Diorio, J. Polymer Sci. Letter to Editor 60, No. 169, S31-S33 (July 1962).

Wave propagation around a curved boundary which contains an obstacle, J. R. Wait, Can. J. Phys. 40, 1010-1016 (Aug. 1962).

Four-place table decibels return loss to magnitude of voltage reflection coefficient, R. W. Beatty, Microwave Eng. Hanb. \& Buyers Guide, p. TD188-192 (Nov. 1961)

Duration and spacing of sferic pulses, R. F. Linfield and C. A. Samson, Proc. IRE 50, 1841-1842 (Aug. 1962).

VHF and UHF signal characteristics observed on a long knife-edge, A. P. Barsis and R. S. Kirby, IRE Natl. Conv. Record, p. 17-34 (1961).

Some observations on growing crystals of argon, L. H. Bolz, H. P. Broida, and H. S. Peiser, Acta Cryst. 15, No. \&, 810-812 (Aug. 1962).

Methods and techniques of low and very low frequency monitoring at Boulder Laboratories, A. H. Morgan and D. H. Andrews, Consultative Committee for Definition of the Second Intern. Comm. on Weights and Measures, Apr. 11-12, 1961, p. 1-10 (June 1961).

Insulation resistance measurements, A. H. Scott, Proc. 4th Electrical Insulation Conf., Materials and Application, Wash. D. C., p. 115-117 (Feb. 19-22, 1962).

Physical measurement: Pilot of progress, A. V. Astin, Steel, p. 112 (July 23, 1962)

Some tensile properties of amalgam, M. S. Rodriguez and G. Dickson, J. Dental Res. 41, No. 4, 840-852 (July-Aug. 1962).

Vacuum photolysis of solid ethane at $77^{\circ} \mathrm{K}, \mathrm{M}$. D. Scheer, J. MeNesby, and R. Klein, J. Chem. Phys. 36, No. 12, 35043505 (June 1962).

Geomagnetic and solar data, J. V. Lincoln, J. Geophys Res. 6\%, No. 5, 2035-2038 (May 1962).

A study of the chemical and physical properties of magnetic recording tape, F. Nesh and R. F. Brown, Jr., IRE Trans. Audio AU-10, No. 3, 70-71 (May-June 1962).

Supporting evidence for solar flare effects in the $\mathrm{F}$ region of the ionosphere, R. W. Knecht and K. Davies, Nature 192, No. 4800, 348-350 (Oct. 28, 1961). 
Measurement of effect of moisture on heat transfer through insulated flat-roof constructions, F. J. Powell and H. E. Robinson, Am. Soc. Testing Materials Spec. Tech. Publ. 312, 35-66 (1961).

Dependence of interval between flare and associated sudden commencement storm on prestorm conditions, M. W. Haurwitz, J. Geophys. Res. Letter 6\%, 2979-2982 (July 1962).

The application of NMR in determination of the structure of cyclanols. I. The structures of cyclohexane-1,3-diols, $\mathrm{H}$. Finegold and H. Kwart, J. Organic Chem. 2\%, 2361-2365 (1962).

APPA-TAPPI reference material program. I. Interlaboratory investigation of TAPPI standard T $414 \mathrm{~m}-49$, internal tearing resistance of paper, T. W. Lashof, Tappi 45, No. 8, 656 (1962).

Spectrophotofluorometric studies of degraded cotton cellulose, S. D. Toner and K. F. Plitt, Tappi 45, No. 8, 681-688 (Aug. 1962).

Algorithm and rapid binary division, R. S. Ledley and J. B. Wilson, IRE Trans. Electronic Computers EC-10, No. 4, 662-670 (Dec. 1961).

Properties of dental amalgams made from spherical alloy particles, N. C. Demaree and D. F. Taylor, J. Dental Res. 41, No. 4,890-906 (July-Aug. 1962).
Emission spectra of solids condensed at very low temperatures from the electrical discharge products of nitrogen and carbon monoxide or acetylene, S. L. N. G. Krishnamachari, R. W. Nicholls, and H. P. Broida, Proc. Indian Acad. Sci. LIV, 61-68 (1961).

Excitation of the red and green coronal lines, C. Pecker and R. N. Thomas, Ann. Astrophys. 25, 100-108 (Mar.-Apr. 1962).

Dependence of the ionospheric F. region on the solar cycle, J. W. Wright, Nature 194, No. 4827, 461-462 (May 1962).

Fast-melting alloy forms water jacket for small klystrons, W. J. Anson and E. Niesen, Electron. Design, p. 42-45 (Mar. 1962).

Boolean matrix equations in digital circuit design, R. S. Ledley, IRE Trans. Electronic Computers EC-8, No. 2, 131-139 (June (1959).

*Publications for which a price is indicated are available from the Superintendent of Documents, U.S. Government Printing Office, Washington 25, D.C. (foreign postage one-fourth additional). Reprints from outside journals or the NBS Journal of Research may often be obtained from the authors. 